\title{
Superficial ecosystem similarities vs autecological stripping: the "twin species" Mesocyclops leuckarti (Claus) and Thermocyclops oithonoides (Sars) - seasonal habitat utilisation and life history traits
}

\author{
Jens Petter NILSSEN* and Svein Birger WÆRVÅGEN ${ }^{1)}$ \\ AbelCentre for mathematics and natural sciences, Division of Natural Sciences, 4980 Gjerstad, Norway \\ ${ }^{1)}$ Hedmark College, Dept for Agriculture and Natural Sciences, Blæstad, 2322 Ridabu, Norway \\ *e-mail corresponding author: jpn@abel.org
}

\section{ABSTRACT}

Mesocyclops leuckarti and Thermocyclops oithonoides, among the most common European species of cyclopoid copepods, immigrated to central Europe from eastern refuges after the last glaciation. M. leuckarti arrived prior to T. oithonoides. In a border region of $\mathrm{T}$. oithonoides in southern Norway, the species was found exclusively below the highest postglacial marine limit, whereas it had spread to other neighbouring lakes above the former marine limit close to its more central region of distribution in eastern Norway. The habitat of M. leuckarti is characteristically both littoral/profundal and planktonic, whereas T. oithonoides is a true planktonic species. The egg sacs of the larger species M. leuckarti protrude from its genital segment, likely increasing water friction. M. leuckarti has probably developed strategies to reduce predation on eggbearing females, such as staying in littoral, profundal or oxygen boundary regions where fish are either absent or experience hunting difficulties. We hypothesise that the numerical suppression of $\mathrm{M}$. leuckarti, its sex ratio, the habitat distribution of adult females, and its life cycles in many eutrophic lakes, is strongly affected by fish predation. M. leuckarti is considerably larger than T. oithonoides; total body length: 1.0-1.3 mm vs 0.7-1.0, respectively. The negligibly coloured and smaller adult $\mathrm{T}$. oithonoides may be outside the prey range for many fish species. In the lowland region, both species completed several numbers of reproductive cycles annually. There were various patterns of diannual and triannual life cycles. Some populations exhibited a conspicuously delayed revival from sediment diapause, others in eutrophic lakes developed slowly during the summer (probably due to naupliar competition from cladocerans), or stayed in the plankton during prolonged periods during autumn. At higher altitudes and in large cold lakes, one generation a year was recorded. In its northern range, M. leuckarti showed sediment diapause in all types of localities, even the deepest lakes, usually in the upper littoral region. In more shallow lakes, deeper diapause sites were observed. T. oithonoides diapaused in either the lower littoral, or the profundal regions. M. leuckarti showed different life cycles in localities within the same geographical region, especially in its southern range. In the shallow part of Bodensee in Germany it entered sediment diapause, whereas in the much deeper main basin it showed plankton diapause (also called "active diapause"). The period of diapause for M. leuckarti (especially in the sediment) decreased from north to south. At about $45^{\circ}$ $N$, sediment and plankton diapause were non-existent, and the species exhibited continuous development, even with relatively low winter temperatures (in Lago Maggiore). T. oithonoides, whose southern distribution in western Europe extends to about $50^{\circ} \mathrm{N}$, showed winter sediment diapause throughout its distribution, but frequently with a fraction of the local population in plankton diapause. The combined effects of these different abiotic and biotic parameters help explain the variations of life histories observed in the field.

Key words: Mesocyclops leuckarti, Thermocyclops oithonoides, life cycles, diapause, habitat selection

\section{INTRODUCTION}

A basic familiarity with life cycles is a prerequisite for analysing life histories. A thorough understanding of autecology is furthermore important for analysing complex ecological systems. This is probably the background for the recent renewed interest in systematics and autecology. If nature is ordered hierarchically, one has to study it (or at least a part of it) hierarchically; if one level of the hierarchy is ignored, connections among the levels are lost. Systematic and taxonomic studies based on life cycles should be promoted; one cannot seriously describe a living species without a thorough knowledge of its life cycle.

The copepod order is one of the most numerous animal groups on the earth (Huys \& Boxshall 1991). It ranges among the more conspicuous members of the aquatic biota and has diversified into a variety of habitats from interstitial sand to parasitic living, damp moss, subterranean localities and plankton. Cyclopoid copepods inhabit the above ecosystems as well. The Cyclopoida is by far the most successful inland-water group within Copepoda, in terms of the diversity within, and the geographical distribution of, their respective groups. Cyclopoid copepods form taxonomically a problematic and difficult group of animals, however. In plankton they are encountered both in neritic and epipelagic marine and freshwater environments, but are more diversely developed in freshwater. Planktonic cyclopoid copepods become progressively more carnivorous during their ontogenetic development. Since they are relatively unspecialised seizers, they will attack a variety of fooditems from bacterial clumps, large algae and small zooplankton to underyearling $\left(0^{+}\right)$fish. The animals deve- 
lop and moult through many larval and juvenile stages (6 naupliar and 5 copepodids) before reaching adulthood, and therefore offer considerable practical and time consuming problems in ecological studies. Several cyclopoid species, similar in shape and size, often coexist in the plankton. In a number of ecological studies, scientists have avoided the pelagic cyclopoids altogether, treating them as Cyclops spp., ignoring that several genera with a variety of life histories are thus being included in the category. Cyclopoid copepods have therefore never achieved a status as popular research animals, like e.g. the genera Daphnia spp. or Chaoborus spp. have. Nevertheless, several researchers have used cyclopoid copepods as test animals, notably in interesting studies on heritability, life history traits and diapause. The "twin species" M. leuckarti and T. oithonoides commonly coexist during similar periods in the plankton of temperate Palaearctic lakes. The genera $\mathrm{Me}$ socyclops and Thermocyclops are usually observed sympatrically in most lakes all over the world. Many scientists underline the close taxonomic and ecological relationships of the species by continuing to place both within the genus Mesocyclops. In many quantitative ecological studies they are also treated together. Nevertheless, a whole array of ecological differences exist between the two species, and the aim of the present paper is to present and synthesise historical and new evidence for these facts.

\subsection{Taxonomical overview}

Along with the genus Cyclops O.F.Müller, 1785, the ecologically most important plankton genera of cyclopoids are Mesocyclops G.O. Sars, 1914 and Thermocyclops Kiefer, 1927. Cyclops is the dominant temperate genus, Thermocyclops the most conspicuous tropical, and Mesocyclops are found within both zoogeographical regions. The most important planktonic cyclopoid copepods were first described in the active taxonomic period in the last part of the $19^{\text {th }}$ century, like the species in the present study: Mesocyclops leuckarti by C. Claus 1857 (as Cyclops Leuckarti) and Thermocyclops oithonoides by G.O. Sars 1863 (as Cyclops oithonoides). Sars later set up the genus Mesocyclops to include both species. Kiefer (1927) shortly after placed T. oithonoides in a separate subgenus under Mesocyclops, and later delimited Thermocyclops as a separate genus by using minute taxonomical criteria. Many systematisists and ecologists disagreed with Kiefer's view and still used Mesocyclops as the common genus for the two species. Sars, on the other hand, claimed that C.L. Koch ${ }^{1)}$ in the 1830 s presented the first recognisable and thus valuable description of what we today classify as M. leuckarti, and Sars consequently used Koch's species name $M . o b$ soletus (Koch). Kiefer $(1928 ; 1978 ; 1981)$ also considered this species conspecific with $M$. leuckarti, but referred to Sars as its primary author (not the Koch authorship, which logically should have had priority). More ta- xonomists expressed doubt concerning Koch's species descriptions, and in the list of species synonymous with M. leuckarti, both Rylov (1963) and Van der Velde (1984) explicitly wrote $M$. leuckarti non C. obsoletus Koch.

Nevertheless, both Sars and Kiefer agreed in what they considered "the remarkable cosmopolitan distribution of M. leuckarti". They were indeed "lumping" a number of species into the M. leuckarti concept. Paradoxically, Kiefer simultaneously acted as a considerable "taxonomic splitter" by creating the subgenus and later genus Thermocyclops from Mesocyclops, a process that started in 1927/1928.

Until the overripe revision of Mesocyclops by Kiefer in 1981 [only 3 years after completing his great account on freshwater copepods in the Binnengewässer 26, Part 2 in 1978, in which he still maintained the usual cosmopolitan approach of $M$. leuckarti (!)], the scientific community was living with the extreme cosmopolitan distribution of its primary species (see also Dussart \& Fernando 1996; Dahms \& Fernando 1993). Several other zooplankton, notably the cladoceran Chydorus sphaericus, also lost their cosmopolitanism in that period (Frey 1980, 1982). Kiefer (1981) delimited the geographical distribution of $M$. leuckarti to the Old World and West Asia, as shown on figure 1A. It is recently claimed that $M$. leuckarti is distributed in Lake Donghu (about $114^{\circ} \mathrm{E}$; Yufeng et al. 1999). For a current distribution of $M$. edax in North America, see Patalas (1986). The geographically more restricted distribution of $T$. oithonoides is shown in figure 1B. Many of the earlier "M. leuckarti" populations changed their nomenclature, even several times, in the turbulent after-

1) G.O. Sars seemed to rely strongly in the species descriptions of C. L. Koch. This was not the only case where he referred to Koch as the origin of the species description. In all the following cyclopoid species Sars claimed priority for Claus. Maybe the skilled taxonomist Sars identified some species characters several of the others were unable to recognise? Nevertheless, it is remarkable that Sars put so much stress upon Koch's original and often earlier descriptions, and considered these recognisable species. In the following, the Koch descriptions within Sars nomenclature are placed first, the original species name follows after: Cyclops vulgaris Koch - $C y$ clops viridis Fischer, C. lucidulus Koch - C. vernalis Fischer, C. pulchellus Koch - C. bicuspidatus Claus, Mesocyclops obsoletus (Koch) - C. Leuckarti Claus, Pachycyclops signatus (Koch) - C. fuscus Schmeil, P. annulicornus (Koch) - C. albidus Schmeil, P. bistriatus (Koch) - C distinctus Richard, Leptocyclops agilis (Koch) - C. serrulatus Fischer. Even more remarkable is the addition Sars $(1918$, p. 211) made in his extremely detailed work on cyclopoid copepods, where he claimed Cyclops pictus Koch should have priority to $C$. strenuus Fischer: "As it appears to me beyond doubt, that Koch's species is the same as subsequently described by Fischer as C. strenuus, I think that, according to the rules of priority, the name proposed by the first named author must be retained for the present species". 
Fig. 1. The present zoogeographical distribution of $M$. leuckarti (A) and T. oithonoides (B). Mainly after Kiefer (1981), and papers referred to in the references. The exact boundaries of both species are uncertain due to too few samples and/or unsettled taxonomy, especially in the eastern regions.

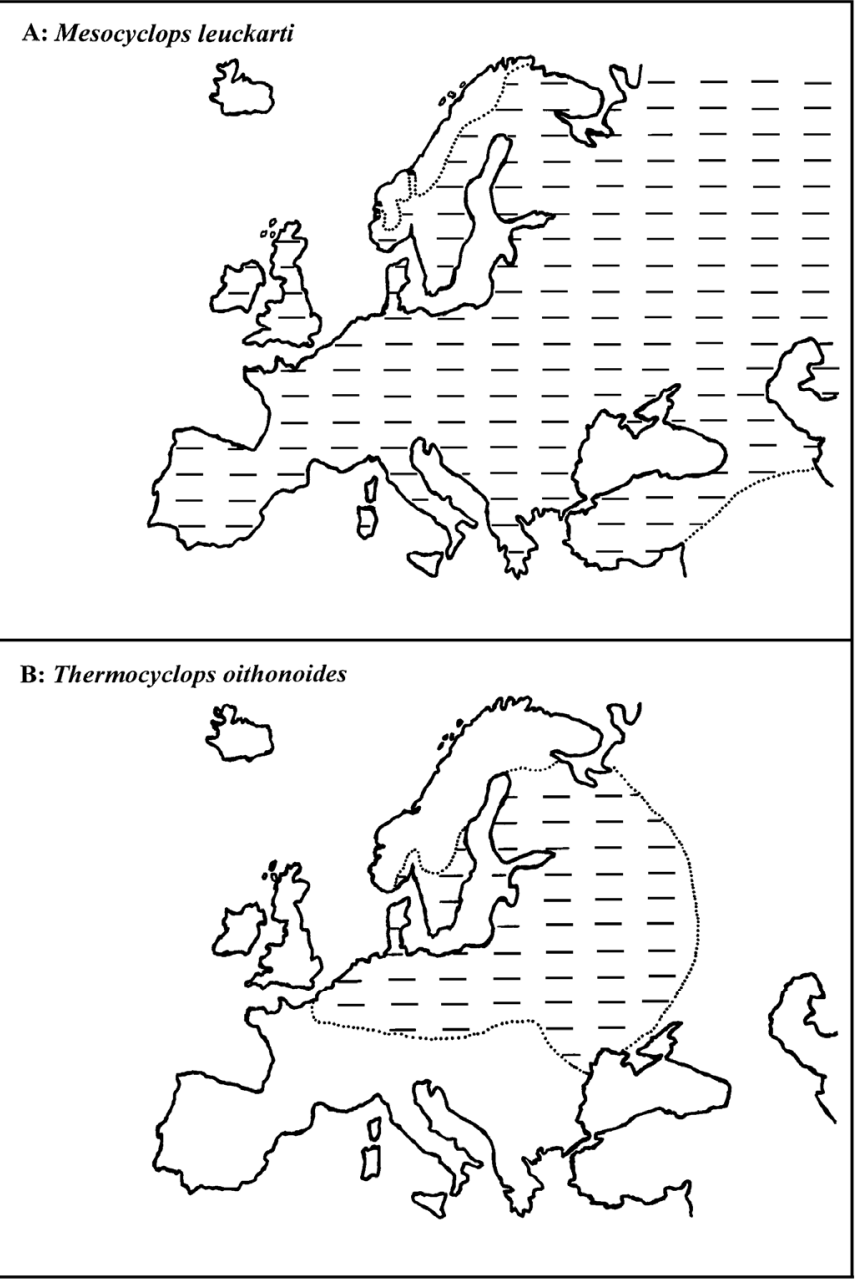

the last decades (Gophen 1988), had its name changed to $M$. thermocyclopoides and thereafter to M. ogunnus. Likewise, the common Mesocyclops in the African great lake area is now M. aequatorialis (Van der Velde 1984). The Lake George (Uganda) Thermocyclops has changed from T. neglectus to T. hyalinus consimilis, according to Burgis (1970). It should be noted that both T. consimilis (Kiefer 1934) and T. neglectus (Sars 1909) are considered separate species by Kiefer (1978), and the common Thermocyclops in Lake George is according to Kiefer (1978), T. crassus.

The problem in identifying $M$. leuckarti and $T$. oithonoides is not straightforward, especially in Continental European lakes, where 3-6 cyclopoid copepods often coexist in the pelagial, and in which populations are dominated by larval and juvenile instars during much of the year. Analyses of life cycles is crucial in ecological research, and considering the 12 different developmental stages, the work often seems overwhelming or practically insurmountable (see Einsle 1989). It is easily understandable that even if rotifers and cladocerans are being counted and processed in detail, the cyclopoid copepods are very often referred to as Cyclo- 

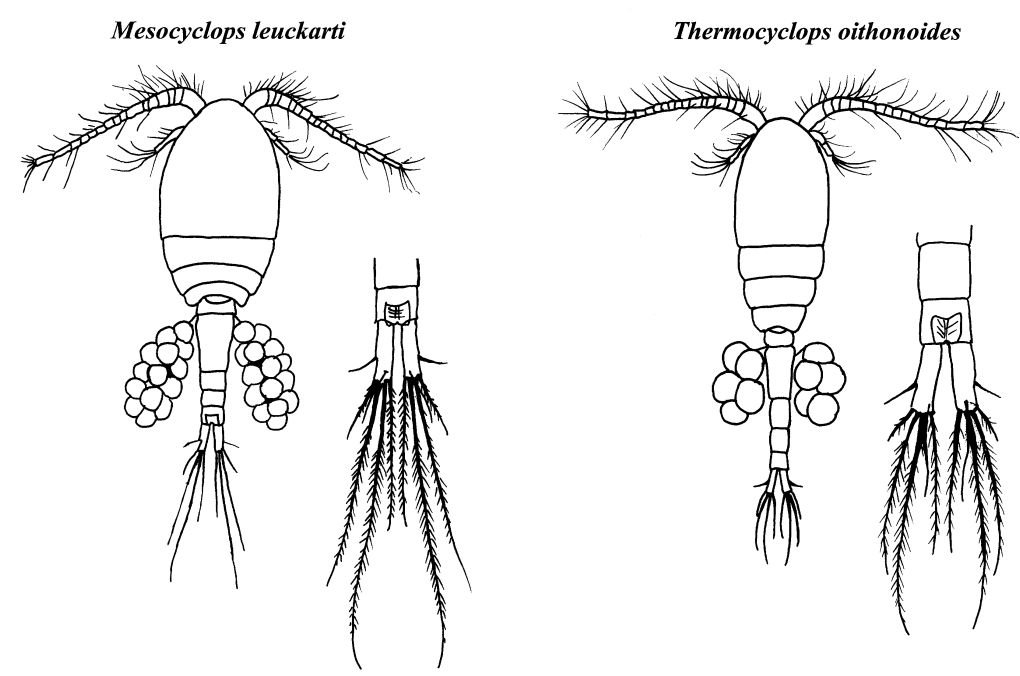

Fig. 2. Important species characteristics of $M$. leuckarti and T. oithonoides. Note position of egg sacs. Based on original drawings by Sars (1918, Plates 35, 36). poidae indet., or Cyclops spp., the latter category usually including several species both of Cyclops, $\mathrm{Me}$ socyclops and Thermocyclops. This is ecologically unfruitful, since in nearly $100 \%$ of the cases, cyclopoid copepods are present in the pelagial of most lakes all over the world.

More serious problems arise when the autecological details of the different species are concerned, and when the species are falsely identified. Figure 2 presents the most important "field" (stereomicroscopic) species characters of $M$. leuckarti and $T$. oithonoides. Notably are the shape of the furcal setae, their internal length relationships, the position and shape of the egg sacs of the gravid females, the general body shape, and the size of the animals. In addition, some ecological parameters are important, notably the altitude of the recorded site, the number of eggs per egg sac, and the habitat distribution of adult females and diapausing copepodids. M. leuckarti is considerably larger, by approximately 20-40 percent (total body length: $1.0-1.3 \mathrm{~mm}$ vs $0.7-1.0$ for $T$. oithonoides), and thus more susceptible to fish predation, especially when carrying egg sacs. Other ecological features will be treated within the scope of this paper.

\section{MATERIAL AND METHODS}

The lakes sampled in Norway involved quantitative (lakes in Fig. 5; Fig. 6) and qualitative sampling (lakes in Fig. 3; Fig. 4) over the deepest parts of the lakes or the depth ranges where $M$. leuckarti and $T$. oithonoides were distributed. The plankton volume sampler was either Schindler/Patalas (10-20 1; Schindler 1969) or Blakar/van Dorn sampler (3-5 1; Blakar 1978). The bottom-sampling was done with a quantitative core sampler, either of the Kajak type (Ø: $7 \mathrm{~cm}$; Kajak 1971) or the Skogheim/Ceev type (Ø: $7 \mathrm{~cm}$; Skogheim 1979).
The qualitative sampling was performed with a plankton net (Ø: $25 \mathrm{~cm}$ ) of mesh size 45 and $90 \mu \mathrm{m}$. Many of the publications by other authors referred to in this paper used plankton nets with different net sizes and/or volume samplers.

\section{DISTRIBUTION: ZOOGEOGRAPHY, IMMIGRATION AND FAUNISTICS}

\subsection{General zoogeography}

The general zoogeography of $M$. leuckarti and $T$. oithonoides is shown in Fig. 1 A-B. It is evident that the two species, like the majority of freshwater species of Europe, immigrated from spatial refuges in the PontoCaspian region after the last Ice Age (Weichselian/Dryas; see Lattin 1967). It is also clear that $M$. leuckarti arrived prior to $T$. oithonoides, since there is no reason to suspect that the dispersal abilities of the species are so different as to have caused the considerable zoogeographical differences registered in countries with efficient dispersal barriers, i.e. Norway (see Figs 3-4), where both species have been investigated in detail. The zoogeographical region of overlap between the two species is delimited by southeastern Norway, southern Sweden and northern Finland, Russia (a notyet-certain eastern distribution of the two species), Ukraine extending south to Odessa, from the Donau delta through northern Austria, southern Germany into France and up to Denmark (Fig. 1). The key-distribution area, where most research has been done on both species, encompasses Poland, Estonia, Germany, Finland and Norway. It is especially the ecology of T. oithonoides that is not so well known. M. leuckarti has been studied in a variety of environments, but details of their its cycle is still insufficiently known, especially habitat selection of the late copepodid and adult stages. 


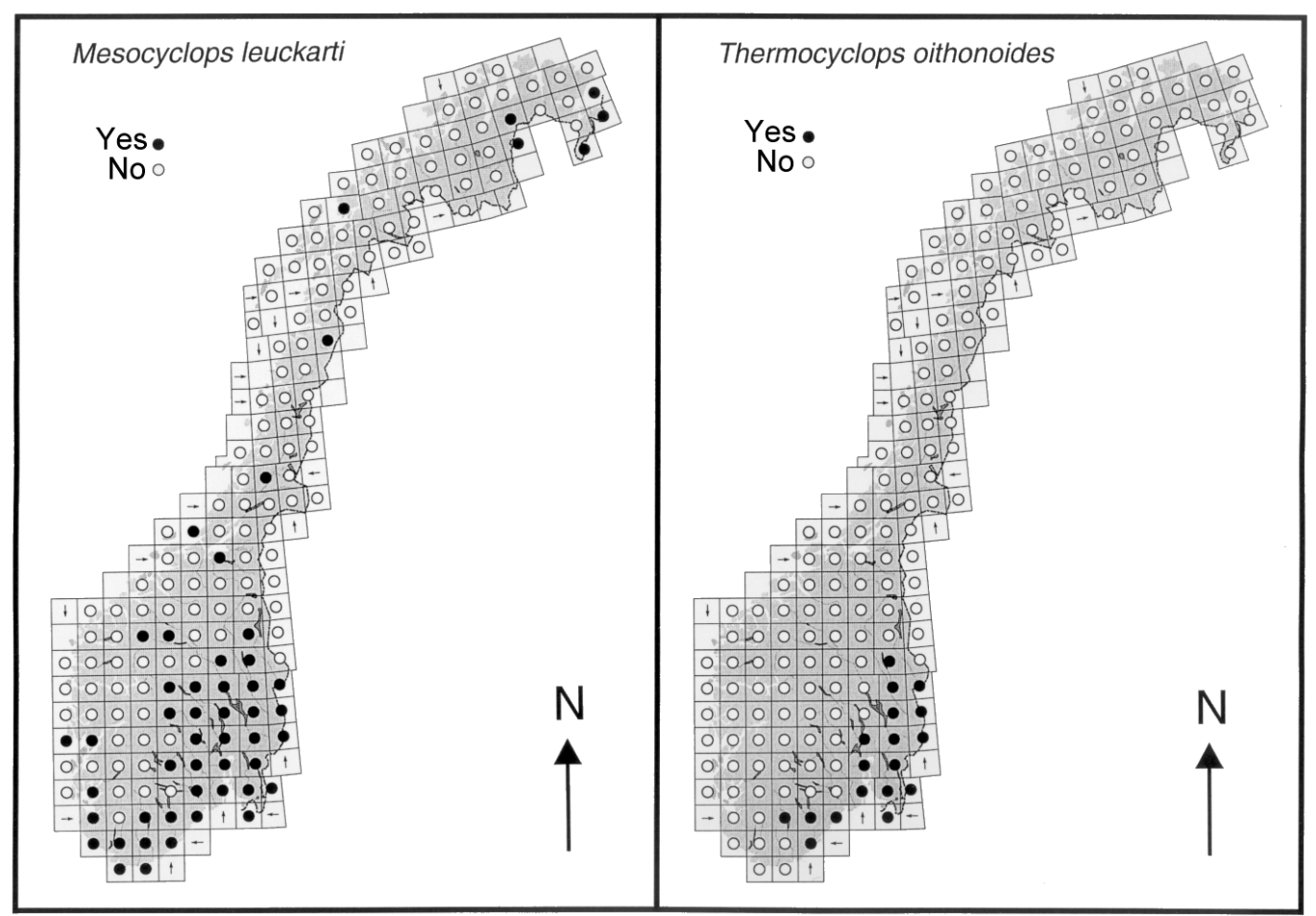

Fig. 3. Present distribution of M. leuckarti and T. oithonoides in Norway (reproduced from Walseng et al., unpubl. 2000).

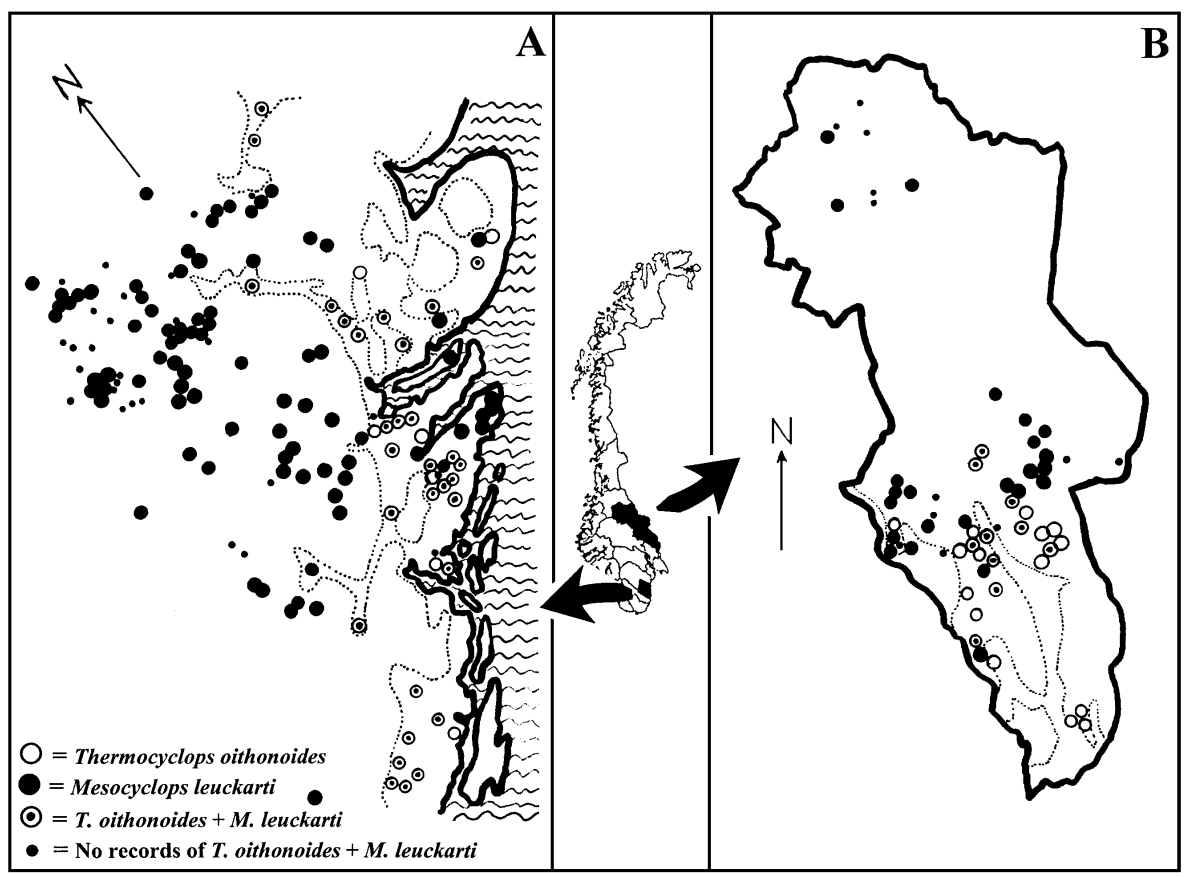

Fig. 4. Zoogeographical analysis of $M$. leuckarti and T. oithonoides from areas A \& B. Dotted line indicates highest postglacial marine limit [in area A (about $100 \mathrm{~m}$ ) and B (about $200 \mathrm{~m}$ ) above present sea level]. Seventeen sites in the western part of area A derive from Halvorsen \& Larsen (1998). 


\subsection{Distribution and habitat characteristics}

\section{a. Scandinavia/Norway}

Zoogeography of $M$. leuckarti and T. oithonoides in Norway is shown in figure 3 (Walseng et al., unpubl. 2000). M. leuckarti has been recorded all over Norway, nearly in all of the regions used for presenting its zoogeography (Aagaard \& Dolmen 1996), whereas $T$. oithonoides was recorded only in the southeastern part (Fig. 3; Walseng et al., unpubl. 2000). It should be noted, however, that $M$. leuckarti does not inhabit mountain regions in Norway (Eie 1974; Nilssen 1976), in agreement with similar conditions further south in Europe. Its distribution all over Norway may therefore be more apparent than real.

Because of its steep profile and variable geomorphology, Norway is an excellent country for studying immigration processes after the last Ice Age (Weichselian/Dryas) in Europe, which ended around 10,000 years ago. Of course, cyclopoid copepods possess very different dispersal mechanisms compared with freshwater fishes. Nevertheless, it is remarkable that M. leuckarti has a similar zoogeographical distribution to the Salmonidae in Norway (naturally occurring in most regions below a certain altitude), whereas $T$. oithonoides having arrived later, possesses a distribution comparable to the earliest Cyprinidae, or a zoogeographical area between that of the Eurasian Perch and the earliest Cyprinidae (Huitfeldt-Kaas 1924).

Two important areas of zoogeography of the two species have been investigated in detail for several years in Norway (Fig. 4). The southernmost area comprises an extreme western distribution of $T$. oithonoides and offers an altitudinal constraint to M. leuckarti. The other area presents the northernmost distribution of $T$. oithonoides, and as well an altitudinal constraint to M. leuckarti. These two areas is further shown in figure 4, where the geographical distribution of the two species are marked, together with altitudinal isoplots, marking the highest postglacial marine limit. M. leuckarti was found in most of the lowland localities, whereas $T$. oithonoides was restricted to the lowland and nearocean sites (area A). T. oithonoides was found in lakes exclusively below the highest postglacial marine limit in area A, whereas $T$. oithonoides had spread to other neighbouring lakes above the former marine limit in area B . Coexistence of the two species was not uncommon, especially in the northernmost region, often co-occurring with heavy fish predation pressure.

The relationships of $M$. leuckarti and $T$. oithonoides to selected physical, chemical and biological parameters are presented in table 1 . These relationships were slightly different in the two regions, and were therefore presented separately. The selected parameters included: altitude, acidity $(\mathrm{pH})$, calcium content, total phosphorous concentrations, humic content, aluminium content (area A), and chlorophyll (area B). M. leuckarti is the most tolerant of the two species, and able to endure hash environmental conditions. T. oithonoides was distributed at lower altitudes than M. leuckarti, especially in southern Norway, where T. oithonoides immigrated later. In both areas, M. leuckarti was tolerant to both acid, as well as eutrophic and alkaline environments, whereas T. oithonoides was absent at $\mathrm{pH}$ levels below 5.4. Both species were tolerant to humic environments (Tab. 1). $T$. oithonoides endured high fish predation better than $M$. leuckarti (Nilssen \& Wærvågen, unpubl. data 19732000). Sandøy \& Nilssen (1987) observed that liming had a very positive effect upon the abundance of $M$. leuckarti, and that reacidification immediately led to lower population numbers. Hessen \& Nilssen (1983) investigated the other side of the $\mathrm{pH}$ spectrum (above $\mathrm{pH}$ : 9.0) in pelagic enclosures placed in the lowland, eutrophic Lake Gjersjøen. High $\mathrm{pH}$ favoured M. leuckarti over T. oithonoides, and vice versa for lower $\mathrm{pH}$ (Hessen \& Nilssen 1983). Furthermore, high pH was characteristic during the eutrophic phase of the investigated lake, and M. leuckarti was the dominant cyclopoid during the peak eutrophic phase in the 1970s. With decreasing trophy, $T$. oithonoides is regaining abundance and is again becoming the dominant cyclopoid (Faafeng \& Nilssen 1981).

Jørgensen (1972), in his comprehensive study on bog successions north of Oslo, found that M. leuckarti inhabited all localities from lakes to very shallow (not temporary) ponds, excluding wet bogs and bogs, and Nilssen (unpubl. data, 1980-84) found that the species inhabited the less saline rock pools (not temporary) close to Risør, in southern Norway. T. oithonoides was recorded in neither of these two areas. M. leuckarti was registered in four lowland ponds in east-central Norway (Elgmork 1964) and three humic ponds (Elgmork et al. 1990) near the timberline in boreal forests in south-central Norway. Furthermore, Jørgensen (1972) observed M. leuckarti in ten localities with $\mathrm{pH}$ between 4.2-4.5, but it was more common with a $\mathrm{pH}$ above 5.0, like in southern Norway (Nilssen 1974, 1980b; Hobæk \& Raddum 1980). Jørgensen (1972) also recorded the plankton/littoral $M$. leuckarti from strongly coloured localities, but it was more common in lakes with higher calcium content, in accordance with Fryer's (1993) observations in northern England. M. leuckarti was also recorded and probably common in sewage-contaminated ponds in Norway (e.g. Källqvist et al. 1996).

Since the early 1970s Nilssen (partly unpubl., 19732000) has sampled or identified zooplankton in many localities, especially in southern and eastern Norway. From these studies it was evident that $M$. leuckarti was common in all sorts of habitats from small, oligosaline rock pools, ponds and littoral zones of lakes to large, lowland lakes. All trophic and predation patterns were included. T. oithonoides showed a more restricted distribution, being absent from the more shallow localities, more acidic environments, and being recorded only 
Tab. 1. Mesocyclops leuckarti and Thermocyclops oithonoides: relationship to habitats and selected physical, chemical and biological parameters in areas A and B (in Fig. 4). Upper and lower extreme values are shown. - : no data.

\begin{tabular}{|c|c|c|c|c|}
\hline & M. leuckarti & T. oithonoides & M. leuckarti & T. oithonoides \\
\hline & \multicolumn{2}{|c|}{ Area A } & \multicolumn{2}{|c|}{ Area B } \\
\hline Altitude (m a.s.l.) & $2-342$ & $0.5-67$ & $200-787$ & $198-443$ \\
\hline Acidity $(\mathrm{pH})$ & $4.6-7.0$ & $5.8-6.8$ & $4.9-8.5$ & $5.4-7.1$ \\
\hline Calcium $\left(\mathrm{mg} \mathrm{l}^{-1}\right)$ & $0.1-10.2$ & $1.5-5.2$ & $1.9-39.0$ & $1.4-32.0$ \\
\hline Tot-P $\left(\mu \mathrm{g} \mathrm{l}^{-1}\right)$ & $3.4-68.1$ & $4.4-26.8$ & $4.5-51.1$ & $4.5-44.3$ \\
\hline Humus (mg Pt l $\left.{ }^{-1}\right)$ & $10-138$ & $15-84$ & $13-201$ & $17-205$ \\
\hline Aluminium $\left(\mu g \mathrm{l}^{-1}\right)$ & $16-250$ & $16-139$ & - & - \\
\hline Chlorophyll $\left(\mu \mathrm{g}^{-1}\right)$ & - & - & $0.2-12.1$ & $0.3-10.8$ \\
\hline
\end{tabular}

in lowland regions, below the postglacial marine limit. A special relationship to predation was found: $M$. leuckarti seemed strongly affected by intensive fish predation by cyprinids, if it did not obtain refuge from predation. In such circumstances, $T$. oithonoides seemed the most successful of the two. In a small, "shoe box"shape, sheltered pond in southern Norway (1: $50 \mathrm{~m}, \mathrm{w}: 5$ $\mathrm{m}, \mathrm{d}: 4 \mathrm{~m}$ ) with steep rocky shores without a littoral area, the following species of cyclopoid copepods were found in dominance order: T. oithonoides, C. strenuus, C. scutifer and M. leuckarti. T. oithonoides was the dominant species of the two, probably because of the combination of high perch predation in the upper water masses, and the lack of a predation refuge for the vulnerable species, $M$. leuckarti. C. strenuus diapaused during summer and $C$. scutifer inhabited the deep, colder waters.

\section{b. Estonia}

Most lakes have been visited in Estonia for studying chemistry, phytoplankton, zooplankton and fish, and a detailed classification of lakes has been undertaken by Mäemets $(1958 ; 1971 ; 1974)$. In nearly all types of lakes both $M$. leuckarti and $T$. oithonoides were important species (Mäemets 1958). The only exception was acid and coloured, shallow and dystrophic lakes, with Eurasian perch (Perca fluviatilis) and pike (Esox lucius), as the only fish species. This group of lakes was characterised by the scarcity of cyclopoids and the presence of the acid-tolerable, fish-predation-vulnerable, carnivorous calanoid Heterocope saliens, like in similar acidotrophic Norwegian lakes (Nilssen 1974, 1980b; Hobæk \& Raddum 1980). Deeper and stratified humic lakes, with higher $\mathrm{pH}$, had more cyclopoids. Here M. leuckarti dominated over T. oithonoides, which supports the former species' improved ability to withstand acidic environments. Lakes close to the sea, or recently isolated from the sea, contained $M$. leuckarti as the dominant species, while T. oithonoides was not recorded (Mäemets 1958). This contrasts with similar habitats in Norway, where $T$. oithonoides most commonly is observed in such localities (cf. Fig. 4). However, M. leuckarti can be found there as well, especially under more eutrophic conditions, and when the invertebrate predator Chaoborus flavicans is common. Other species of cyclopoids in the extensive Estonian lake classification study were in decreasing order of abundance: C. scutifer, C. kolensis, $T$. crassus ( $=T$. hyalinus), $C$. abyssorum, and C. lacustris. Lakes with $C$. scutifer as the characteristic species, harboured most cyclopoids. These lakes were furthermore eutrophic, and rich in lime (Mäemets 1958; 1971).

c. Poland

Poland is situated within the same biogeographical region as neighbouring Estonia. Pelagic plankton in Poland was studied regionally starting in the 1950 s by Patalas \& Patalas (1966) and continued by e.g. Karabin (1983), based on earlier zoogeographical studies by seniors as Litynski, Gajl, Kozminski, Rzoska and others. $M$. leuckarti and T. oithonoides were distributed over most of Poland, but their ecological parameters were slightly different. T. oithonoides dominated in mesotrophic environments, whereas $M$. leuckarti dominated in eutrophic, dystrophic and pond environments. The clearest differences were the pond and acid environments. The predominance of $M$. leuckarti in eutrophic lake sub-areas and localities (Szlauer 1958; Gieysztor 1959; Patalas \& Patalas 1961; Hajduk 1966), ponds (Prószynska 1963; Kowalczyk 1969), and acid environments (Hajduk 1966) have later been noted by a number of authors. A similar distribution of $M$. leuckarti to Mäemets (1958) in oligosaline environments was recorded by Guttowa (1956). The dominating species in an estuarine area on the Baltic coast was M. leuckarti, whereas $T$. oithonoides was only recorded at one station. Saline inflow (transporting food elements?) furthermore stimulated egg production of $M$. leuckarti, and a sharp rise in abundance followed such saline inflow periods.

\section{d. Russia}

Rylov (1963) identified M. leuckarti in most of European Russia and Siberia, but this was prior to the taxonomical and zoogeographical revision by Kiefer (1981). Its eastern distributional limit remains uncertain from the present information available. The general habitat distribution of the two species was as recorded in 
the aforementioned countries. Skadovski (1926) showed that the eggs of M. leuckarti can hatch at as low $\mathrm{pH}$ as 3.0, but the nauplii died rapidly at a $\mathrm{pH}$ below 4.5 .

\section{e. Germany}

M. leuckarti is common over most of Germany, but does not penetrate into the high mountain areas of southern Germany (Kiefer 1978). Herbst (1951) found that M. leuckarti, together with Eucyclops serrulatus, were the most common copepods in small-sized environments, including perennial ponds, acid waters and brackish water, whereas $T$. oithonoides was not recorded. Maier \& Buchholz (1996) reported that M. leuckarti was one of the most common species in gravel pits at all trophic levels, but also reported that $M$. leuckarti and Eudiaptomus gracilis were less common in the eutrophic group of the investigated lakes (also see Maier 1996). Both these epilimnetic species are highly susceptible to fish predation when carrying eggs; their distributional patterns in such lakes could therefore be due to fish predation, especially by juveniles $\left(0^{+}\right)$. In Plöner lakes both species were recorded (Herbst 1955; Kiefer 1978). Furthermore, the habitat distribution of the two species was similar to Scandinavia, Estonia and Poland. $M$. leuckarti was often recorded in the littoral zone during summer (Herbst 1955), during the the so-called "clearwater phase".

\section{f. UK and Ireland}

Only M. leuckarti, not $T$. oithonoides, is recorded in the British Isles and Ireland (Eire), but $T$. crassus $(=T$. hyalinus) is found. M. leuckarti co-occurs with $C$. abyssorum in this region, but $M$. leuckarti tend to be distributed further south due to its warm-water and lowland preferences. In the region of the English Lake District they co-occur, however. In the British Isles, Gurney (1931-1933) described $M$. leuckarti as a species common both in ponds and in the plankton of lakes. Smyly (1957) recorded the species among macrophytes in moorland ponds near Windermere, but Fryer (1993) observed in Yorkshire that it was an "inhabitant of open water with a strong preference for large water bodies".

\section{LIFE HISTORY TRAITS}

\subsection{Seasonal abundance and life cycles}

\section{a. Scandinavia and Norway}

The generalised life cycle patterns of the two species, shown in figure 5, originate mainly from Norwegian sites. The main fraction of the species populations was present in the plankton from April/May to September/October (Elgmork 1964; Wærvågen 1985). Wintering in diapause, in copepodid stages IV-V, usually took place in the sediments. Alternatively, a small fraction of the populations (in Norway $T$. oithonoides) used the plankton as a diapausing habitat (also see Naess et al. 1993). This was denoted "active diapause" by Halvorsen
\& Elgmork (1976), when analysing C. scutifer in two deep fjord-type lakes. $M$. leuckarti rested in shallow sediment areas, whereas $T$. oithonoides rested both in shallow and/or deeper areas (Elgmork 1958, 1964, 1973; Elgmork et al. 1990; Larsen 1982; Nyberg 1982; Sandøy 1984; Wærvågen 1985; Naess 1985; Demmo 1985; Brabrand et al. 1987). The intensity of diapause ("torpor") was usually not so deep in the two species, compared to Cyclops s. str., and the copepodids did not bury so deep into the sediments as the Cyclops s. str. species. In one investigated lake, M. leuckarti cop IV had significantly deeper torpor than cop V (Elgmork \& Nilssen 1978; Elgmork 1996), but the knowledge of diapause development is much more restricted than for Cyclops spp. (cf. Elgmork \& Nilssen 1978).

The most common life cycle of $T$. oithonoides was two or three generations a year. In the lakes where the species entered diapause in summer (Lake Vormelitjenn), it gave rise to only two generations a year, whereas in the localities where it entered diapause in autumn (Lake Bosviktjenn), it might produce three generations yearly. For a more comprehensive discussion see Naess et al. (1993). Elgmork (1958) suggested two yearly generations for $T$. oithonoides in a eutrophic lake (Lake Bergstjern), but it could also have a minor third generation, as observed in another eutrophic lake (Lake Gjersjøen; Brabrand et al. 1987). In Lake Créteil, France, diapause was terminated very late during summer, and the species was therefore able to produce only two generations annually (Lacroix \& Lecher-Moutoué 1984). In some lakes (Lake Skuggetjenn) M. leuckarti produced both diannual and triannual life cycles, depending upon yearly variations in the habitat temperatures (Sandøy 1984). There were several patterns of diannual and triannual life cycles. Some populations of the two species exhibited a conspicuously delayed revival from sediment diapause (Lake Créteil: T. oithonoides), others in eutrophic lakes (M. leuckarti: Lake Mikolajskie, Lake Borrevann) developed slowly during the main summer (probably due to naupliar competition from cladocerans; Santer \& Lampert 1995), and others stayed in the plankton during prolonged periods during autumn ( $M$. leuckarti: Lake Borrevann). All these different selection pressures from abiotic and biotic parameters combine to produce the variable patterns of life cycles observed in the field.

$M$. leuckarti developed more rapidly than $T$. oithonoides both in laboratory and in field enclosures (Herzig 1983; Hessen 1982; Oksum-Eriksen 1982). More varieties were recorded in its life cycle patterns, from one to three generations (and probably more) a year (Elgmork 1964; Elgmork et al. 1990; Larsen 1982; Nyberg 1982; Papinska 1984; Sandøy 1984; Wærvågen 1985; Maier 1990; Halvorsen et al. 1996; Nilssen, unpubl.data 19791981). It is difficult, however, to identify single cohorts when they increase above three generations per year. Halvorsen et al. (1996) recorded two generations per 


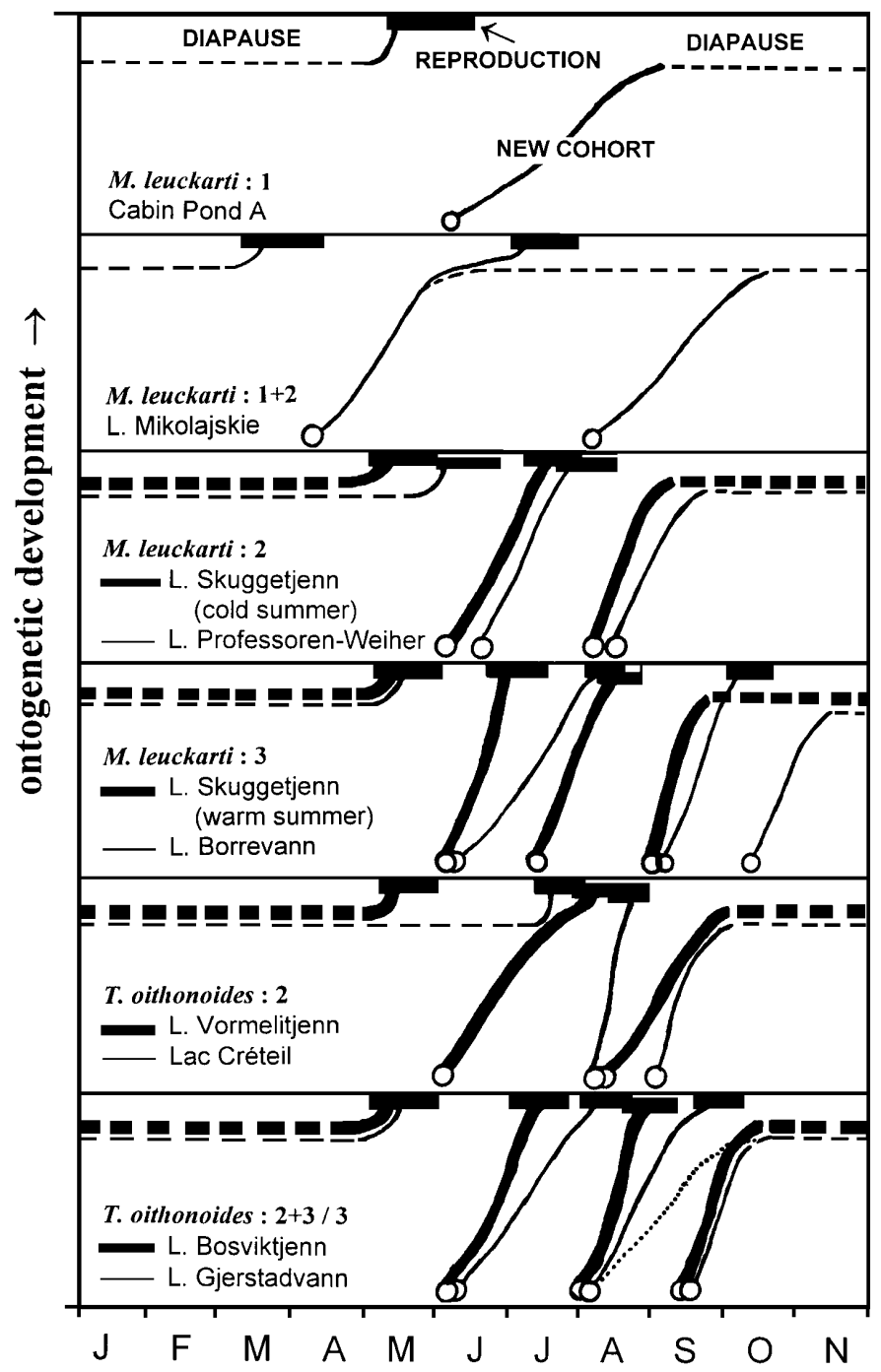

Fig. 5. Life cycles of selected populations of $M$. leuckarti and T. oithonoides; occurrence of different stages and rate of development (semi-diagrammatic). Legend to life cycles as in Cabin Pond A. The development patterns for the different populations are redraw from: Cabin Pond A (annual cycle: 1; Elgmork et al. 1990), Lake Mikolajskie (combination of annual and diannual cycles: $1+2$, note the alternative routes of the early summer cohort; Papinska 1984), Lake Skuggetjenn (diannual or triannual, depending upon summer temperatures: 2 or 3; Sandøy 1984), Lake Professoren-Weiher (diannual cycle: 2; Maier 1990), Lake Borrevann (triannual cycle: 3; Nyberg 1982), Lake Vormelitjenn (diannual cycle: 2; Naess et al. 1993), Lac Créteil (diannual cycle: 2; Lacroix \& Lecher-Moutoué 1984), Lake Bosviktjenn (triannual cycle: 3; Naess et al. 1993), Lake Gjerstadvann (combinations of diannual and triannual cycles: $2+3$, dotted cohort: alternative diannual cycle; Wærvågen 1984). More details in the text.

year in Lake Randsfjorden, whereas in the shallower and warmer delta region, a combination of two and three generations per year predominated. Also with $M$. leuckarti, similar variations like the life cycle patterns of $T$. oithonoides, were recorded.

Adult females of $M$. leuckarti with egg sacs are more vulnerable to predation than earlier ontogenetical stages and males (see predation chapter; cf. Winfield \& Townsend 1983), and will migrate from the plankton into shallow areas, often with dense macrophyte coverage. This is observed in many Norwegian lakes (Sandøy 1984; Sandøy \& Nilssen 1987; Elgmork et al. 1990; Nilssen, unpubl. data 1979-1981). This is supposed to be a predation avoidance strategy of the species (cf. Winfield \& Townsend 1983). However, this pattern is also found when no fish predators are present (Sandøy 1984; Elgmork et al. 1990; Nilssen, unpubl.data 1979-1981), suggesting that other selective factors may also apply; abundant food and high temperatures. $M$. leuckarti has been found to utilize detritus as food (Papinska 1985), and maybe such shallow littoral zones offer additional periphytic and detritus food sources for the adults. Furthermore, the much higher temperatures offer more rapid development of the eggs and a possibility to produce more eggs at shorter time intervals (cf. egg development time; Taube \& Nauwerck 1967; Herzig 1983). However, in a lake with very low fish predation, Larsen (1982) recorded adult females with eggs in the plankton, and the sex ratio was close to one most of the year. This indicates a considerable influence on fish predation on life history traits in many species populations of M. leuckarti (see Nilssen 1977; 1980a for a discussion on fish predation and life history patterns of other cyclopoid copepods). The behaviour in fish-less lakes may be due to a strong inherited characteristic, deeply rooted in the genotype of the species. 
In Norwegian lakes both M. leuckarti and T. oithonoides inhabit the epilimnion, $T$. oithonoides seemed to be distributed slightly deeper in the watermasses than M. leuckarti (Wærvågen 1985). In lakes without $M$. leuckarti, T. oithonoides was found closer to the surface (Naess 1985; Demmo 1985). The plankton distribution is also reflected in the bathymetric depth distribution of the resting sediment stages, (cf. Fig. 6), where some Norwegian populations of the two species are shown together with some European populations. M. leuckarti selected generally the shallow littoral areas for sediment diapause. A striking exception was Lake Mikolajskie, where nevertheless the resting habitat selection differed strongly within various years (Papinska 1984), and as well included years with shallow habitat selection. $T$. oithonoides was distributed at deeper strata, in some lakes at maximum depths exclusively (Lakes Vormelitjenn and Gjerstadvann). In Lake Pääjärvi the maximum abundance of the two species occurred at similar depth (1-2 m), but only $T$. oithonoides was common at greater depths (Sarvala 1979). With sympatric occurrence of the two species, M. leuckarti was found in the shallow littoral, whereas $T$. oithonoides inhabited most depths, especially the deepest region (Fig. 6). Elgmork (1959; 1973) observed that resting copepodids accumulated near the chemocline in meromictic lakes, but also that some specimens penetrated the monimolimnion and was found at the deepest regions. by filtrating with a $90 \mu \mathrm{m}$ net, allowing $M$. leuckarti to develop alone with ample food, a full cycle was nearly completed in a little more than 2-3 weeks (Hessen 1982).

The reproductive patterns, including clutch sizes, of the two species contrast conspicuously. Egg sacs of $M$. leuckarti are larger, and contain more and smaller eggs (see Fig. 2). Czeczuga (1960) investigated this in several Polish lakes, and found interesting patterns. The present lakes were compared with some eutrophic European lakes (Fig. 7). Clutch size usually decreased from spring to summer and autumn, more pronounced in the predation-vulnerable species $M$. leuckarti than $T$. oithonoides. $M$. leuckarti exhibited a medium clutch size between 20-30, whereas T. oithonoides showed medium egg numbers between 7-15. In the oligotrophic Lake Gjerstadvann, both $M$. leuckarti and T. oithonoides produced comparable egg numbers to eutrophic lakes both in Norway and Europe. Since females with egg sacs use the littoral as an additional habitat in many European lakes, measurements on egg numbers of $M$. leuckarti are difficult available. The Estonian Lake Võrtsjärv, formed a conspicuous exception, since $M$. leuckarti exhibited low clutch sizes throughout the whole reproductive season.

The relationship to fish predators can be studied in neighbouring lakes in southern Norway where popula-

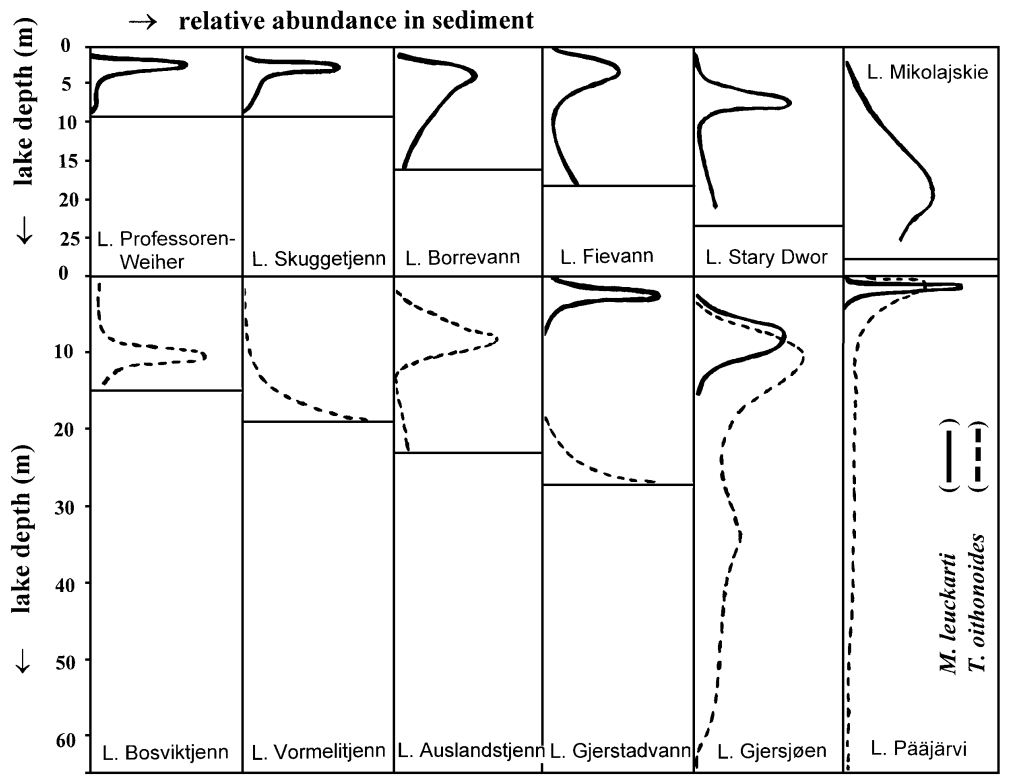

Fig. 6. Bathymetric distribution of the sediment resting stages in selected populations of $M$. leuckarti and T. oithonoides (relative abundance). Species legend as in Lake Pääjärvi. Maximum depth of the different lakes is shown. The curves for the different populations are redraw from: Lake Professoren-Weiher (Maier 1990), Skuggetjenn (Sandøy 1984), Lake Borrevann (Nyberg 1982), Lake Fievann (Larsen 1982; few samples, especially in littoral), Lake Stary Dwor (Szlauer 1963), Lake Mikolajskie (Papinska 1984; pattern differed conspicuously between years), Lake Bosviktjenn (Demmo 1985), Lake Vormelitjenn (Naess 1985), Lake Auslandstjenn (Wærvågen, unpubl. data 1980-85), Lake Gjerstadvann (Wærvågen 1985), Lake Gjersjøen (Brabrand et al. 1987), Lake Pääjärvi (Sarvala 1979). More details in the text.

Santer \& Lampert (1995) presented clear evidence for a strong competition between larval stages of cyclopoid copepods and cladocerans. In enclosure experiments it was found that the two species developed slowly during the warm water period when cladoceran competitors were present (Hessen 1982; Oksum-Eriksen 1982). However, when the competitors where removed tions are subject to contrasting predation patterns. In lakes with small populations of brown trout (Salmo trutta) as the only fish present, only $M$. leuckarti was found (Nilssen 1974; 1980a; unpubl.data, 1973-2000; Larsen 1982). When fish predation (either by Eurasian perch (Perca fluviatilis) or cyprinids) was intense, both species were found (Nilssen \& Eie 1974; Nilssen \& 
Wærvågen unpubl.data 1973-2000). In eutrophic lakes with contrasting trophy and fish predation, the two species differed in their horizontal distribution in that $T$. oithonoides was able to better endure this predation (Bjørndalen \& Warendorph 1982).

The above observations were also made in the other Scandinavian countries (Wesenberg-Lund 1904; Røen 1957; Nauwerck 1963; Hakkari 1969; Granberg 1970). Both Halme (1958) and Koski et al. (1999) recorded $T$. oithonoides in a freshwater-dominated coastal area in $\mathrm{S}$ Finland. Wesenberg-Lund (1904) stressed that in the predation-dense lakes in Denmark, $T$. oithonoides was the exclusive plankton representative, but under specific circumstances (eutrophy, large littoral or shallow areas) M. leuckarti might inhabit the plankton. Røen (1957), also observed that $M$. leuckarti and $T$. oithonoides occupied acidic environments ( $\mathrm{pH}$ below 5.0), but only $M$. leuckarti was recorded in saline habitats. Rodhe (1941) found that $M$. leuckarti was generally distributed closer to the surface than $T$. oithonoides in three lakes in midSweden. Sarvala (1979) reported that the onset of dormancy of the two species was gradually postponed from north to south, and that their reappearance in spring occurred later in the northern localities. Populations of $M$. leuckarti (where information was available) in large, big lakes in the same latitude behaved differently in that they disappeared later in autumn and revived later in spring than more shallow, smaller localities (Sarvala 1979). He (Sarvala 1979) also reported that the regularity of winter dormancy seemed to break down in southern Germany and Switzerland where benthic dormancy may or may not occur (Einsle 1964a; 1969a; Mittelholzer 1970), and in northern Italy where benthic dormancy was wholly absent (Smyly 1964). In Lago Maggiore two annual generations were produced (Ravera 1954).

\section{b. Estonia}

Cyclopoid copepods in the large, shallow and nonstratified Estonian Lake Võrtsjärv was investigated by Schönberg (1961). Both species, M. leuckarti and $T$. oithonoides, diapaused during winter as cop. IV-V. They were present in the plankton from April (M. leuckarti) or early winter (T. oithonoides). A fraction of the latter species was planktonic in an "active diapause" phase, like many other species populations (Naess et al. 1993). M. leuckarti disappeared from the plankton in September. T. oithonoides was still present at the final sampling date in November, supporting the above hypothesis concerning an alternative over-wintering habitat of $T$. oithonoides. The sex ratio of $M$. leuckarti was close to unity throughout the year, as observed in many other large lakes. Nevertheless, a considerable part of the population was always recorded close to the benthic region (Schönberg 1961), as observed elsewhere. The sex ratio of $T$. oithonoides in Lake Võrtsjärv was also close to unity throughout the year. T. oithonoides produced two generations a year, and $M$. leuckarti produced two full generations and one abbreviated cohort during one year; this latter behaviour has been suggested for both species in several European localities. The egg numbers of the two species decreased sharply from spring to summer. $M$. leuckarti produced about 24 eggs per egg-bearing female in spring, decreasing to 14 in summer. The numbers for T. oithonoides was 14 and 6 , respectively (see also Fig. 7).

c. Poland

A number of studies have been performed on the

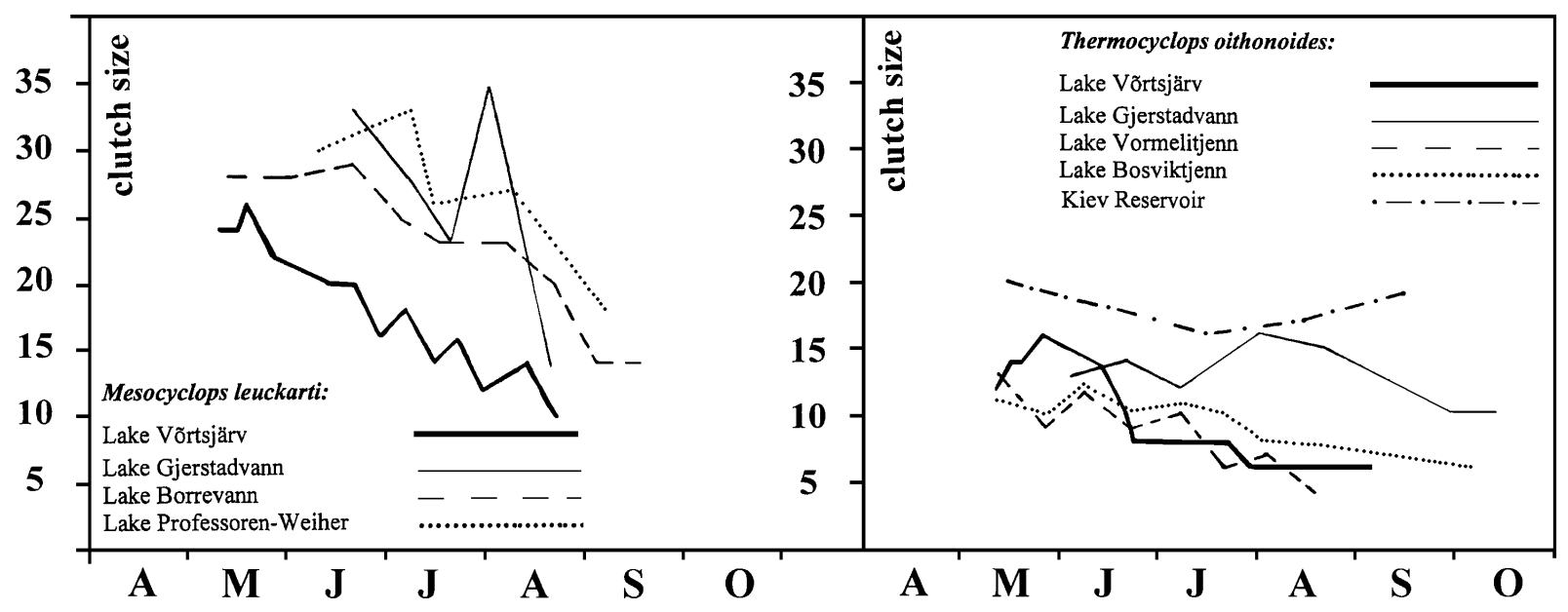

Fig. 7. Seasonal variation in clutch size (total eggs per egg-bearing females) of different populations of M. leuckarti and T. oithonoides. The curves for the different populations are redraw from: Lake Vorrtsjärv (Schönberg 1961), Lake Gjerstadvann (Wærvågen 1985), Lake Borrevann (Nyberg 1982), Lake Professoren-Weiher (Maier 1990), Lake Vormelitjenn (Naess 1985), Lake Bosviktjenn (Demmo 1985), Kiev Reservoir (Zhdanova \& Frinovskaya 1979). More details in the text. 
two species in Poland, another "complicated cyclopoid country", with a long tradition in hydrobiology, including many studies of the two species. Patalas started an intensive study on habitat selection and life histories of Polish cyclopoids in the 1950s. This was the start of a modern plankton research tradition in that country, with a number of time-consuming quantitative zooplankton studies. Many of these included $M$. leuckarti and $T$. oithonoides, as in the $30 \mathrm{~m}$-deep, eutrophic Lake Jeziorze. T. oithonoides appeared here earlier in the season (early March) and disappeared later (December/January) compared with $M$. leuckarti (early April, and late November, respectively). The abundance of the two species was similar, with $T$. oithonoides slightly more common. Other important cyclopoids were $C$. abyssorum and $C$. kolensis (Patalas 1956). A number of quantitative studies earlier and later supported this seasonal occurrence of the two species (Patalas 1954a; Patalas 1963; Patalas \& Patalas 1961; 1968; Kowalczyk 1958; Szlauer \& Widuto 1966), but in a few localities $M$. leuckarti occurred at the same time (Bittel et al. 1965) or even prior to T. oithonoides, like in Jeziorak (Zawislak \& Bittel 1971) and some lakes in Libiszow/Lublin (Kowalczyk 1958), the ecological reasons for which will be discussed in the diapause section. In a few lakes both species were found in the plankton in small numbers during winter (Patalas \& Patalas 1968).

In Polish lakes, $T$. oithonoides is usually distributed in deeper strata than M. leuckarti (Patalas 1954a), therefore Patalas (1963) called T. oithonoides a species characteristic for the lower epilimnion or metalimnion. Other studies have supported these observations (Bittel 1964; Szlauer \& Widuto 1966). Patalas (1954a) registered, a slight diurnal vertical migration for the two species at different times of the year, in that they moved upward during the dark part of the $24 \mathrm{~h}$ period.

Papinska $(1984 ; 1985)$ has published one of the most detailed studies on M. leuckarti. She (Papinska 1984) found that $M$. leuckarti formed dense sub-populations in the near-bottom layer (see also Papinska \& Prejs 1979; Prejs \& Papinska 1983), probably feeding on the detritus in the bottom sediments (Papinska 1985). Above the bottom sediments, $M$. leuckarti occurred most of the year. The life cycles of the 37 lakes in northern Poland she studied (Papinska 1984), had cohorts with two generations a year following three different life history patterns: one with a diapause (in cop. IV) lasting for about 9 months (June-March), a second without diapause, and a third with diapause (in cop. V) lasting for about 5 months (October-March).

\section{d. Russia}

Russia forms another centre of overlap between the two species. Their seasonal dynamics have been investigated by several authors. The findings are comparable to Poland and Estonia, but several populations of $M$. leuckarti show an "active diapause" in the profundal habitats of some lakes in Ural (Ulomski 1953), and in the Rybinsk Reservoir (Monakov 1959). A considerable amount of work has been done in the former USSR on the feeding and diet of crustaceans (for reviews see Monakov 1972, 1976; Sushchenia 1975), but it is beyond the scope of this paper to summarise all this information. Monakov $(1972,1976)$ stated that the diet of $M$. leuckarti and T. oithonoides are similar, being composed by smaller crustaceans, protozoans and rotifers for late ontogenetical stages and adults. The seasonal occurrence and vertical distribution of the two species is simliar to earlier observations (River et al. 1982; Markevich et al. 1982; Stolbonuva 1985). The dominant life cycle of the two species was two generations annually (Rylov 1963; Alekseev 1987). Alekseev (1990) made a comprehensive study on diapause in crustaceans, including cyclopoids.

\section{e. Germany, Switzerland and Austria}

The ecology of the two species in Germany is similar to the findings from Scandinavia and Poland, but in southern Germany M. leuckarti is present both in the sediment and in the free water. Herbst (1955) found that for both these epilimnetic species, M. leuckarti was recorded above T. oithonoides in the Grosse Plöner See (see also Maier 1993). There was also a tendency for a more pelagic "active diapause" in $T$. oithonoides in this lake (Herbst 1955). Maier (1990) observed two annual generations of $M$. leuckarti in a small shallow, eutrophic lake. The distribution and annual cycle of $M$. leuckarti in Bodensee is an interesting case, with two different manifestations of diapause (Einsle 1964a). In the shallow Gnadensee (Untersee) it entered sediment diapause as cop $\mathrm{V}$, whereas in the main, and very deep part of the lake (Obsersee) it endured a planktonic diapause, socalled "active diapause" (Einsle 1964a; see also Kiefer $\&$ Muckle 1959; M. bodanicola $=$ M. leuckarti). In the neighbouring lake to Gnadensee, Mindelsee, M. leuckarti is absent from the plankton only during mid-December to mid-January (Einsle 1964b; Einsle 1969a). Einsle (1964a) was not able to identify the number of cohorts during summer, but stressed the simularity of Smyly's (1961) observations of two generations a year. Even if $M$. leuckarti is distributed in the epilimnion, it showed considerable upwards vertical migration during the $24 \mathrm{~h}$ cycle (Einsle 1969b, 1987). The abundance of M. leuckarti during the period 1962-1986 was investigated by Einsle $(1983,1988)$, and showed a temporary decrease during the most intensive eutrophication period in the 1970s. M. leuckarti has now again increased its abundance, which could be due to decreased predation by Cyclops vicinus (Einsle 1983, 1988), and probably also to changes in fish predation with decreasing trophy.

The eutrophic Swiss Greifensee, with a maximum depth of only $32 \mathrm{~m}$, is situated close to Zürich, whereas Viervaldstättersee, with a maximum depth of $214 \mathrm{~m}$, is 
close to Luzern. The life cycle of $M$. leuckarti in the two lakes differed in that it endured winter in sediment diapause in the shallow lake, but stays in the plankton in "active diapause" in the deepest lake (Mittelholzer 1970), comparable to the Bodensee population. He (Mittelholzer 1970), also reported a tendency of $M$. leuckarti to be distributed in the littoral areas. In Lake Biel (= Lac Neuchatel) the yearly abundance of $M$. leuckarti was similar to that in Bodensee (see Einsle 1964a), where the species overwintered in two fractions, one in the sediment and the other in the deep water above sediments (Stebler 1979).

In the large, but relatively shallow Ossiachersee in southern Austria, Wappis (1980) recorded sediment diapause in $M$. leuckarti, and it disappeared from the plankton during mid-winter. In the much deeper Attersee, Moog (1979) found only plankton diapause, and the species completed two generations a year.

Frenzel (1977) found in a eutrophic lake three yearly generations of $T$. oithonoides with a short, probably sediment diapause during mid-winter. A part of the population also inhabited the plankton during winter (Frenzel 1977). Advanced copepodid and adult stages partly inhabited the hypolimnion during the warm period, with a vertical migration towards upper strata during night for all stages (Frenzel 1977). A similar distributional pattern was found in Lake Stechlin (Kasprzak \& Schwabe 1987), where, uncommonly, M. leuckarti was distributed below T. oithonoides. Such distribution could have been due be due to fish predation, but this was not reported.

\section{f. The Netherlands and France}

Vijverberg (1977) investigated the cyclopoids of the shallow Lake Tjeukemeer. He (Vijverberg 1977) did not report numbers of cohorts for $M$. leuckarti, but it was present in the free waters from March to October/November, and endured sediment diapause the rest of the year. Predation on females was probably keen during the period of maximum occurrence of fish fry in June-August (Vijverberg 1977). Vijverberg \& Richter (1982) reported the conspicuous tendency of M. leuckarti to be distributed close to the bottom, an area which could not be sampled by their method. This could be corroborated by the composition of the major fish (bream, Abramis brama) diet, which contained a large number of adult copepods, including $M$. leuckarti.

T. oithonoides was also found in northern France. In Lake Créteil two generations a year were produced, with diapause mainly in the sediments, and a minor fraction in "active diapause" in the plankton (Lacroix \& Lecher-Moutoue 1984). This population terminated diapause very late in the summer (Lacroix \& LecherMoutoue 1984). Amoros (1973) found sediment diapause in $M$. leuckarti in three fishponds from October to April, and these populations produced probably 2-3 generations annually, if based upon his figures (Amoros
1973) and the findings of Lacroix \& Lecher-Moutoue (1984).

\section{g. UK}

Several studies on $M$. leuckarti have been undertaken in the British Isles. Here, Fryer \& Smyly (1954) published resting stages of cyclopoids without a cyst (a gelatinous sheat; see Birge \& Juday 1908; Cole 1953; 1955) in the benthos of Esthwaite Water for the first time. M. leuckarti usually left the limnetic zone in winter and spent October to February/March dormant in the bottom sediments as parts of its life cycle (Smyly 1961; 1968). The species produced two generations during one year, with two egg-laying periods: April/May and June to August. In the colder, oligotrophic Loch Lomond, $M$. leuckarti produced one generation during one year, and diapause differed also from the most common types described (Chapman 1972). The species was observed in the plankton year-round. A small fraction rested in the sediment during winter, whereas the majority exhibited an arrested development similar to "active diapause" in the deep waters as copepodid stages IV/V (Chapman 1972). The initiation of dormancy coincided with the autumn circulation period and the associated temperature decrease, whereas the termination of the dormant period was not clearly related to any environmental change (Smyly 1961).

\subsection{Trophic status, seasonal occurrence and ontogenetical 'bottle-necks'}

Cyclopoid copepods exhibit eleven larval and juvenile stages and one adult stage. Many of the larval stages of summer species, like $M$. leuckarti and T. oithonoides, face dense competition from rotifers and especially cladocerans (summary by Nilssen 1978). In late spring and early summer, when cladocerans dominated the plankton, Santer \& Lampert (1995) found that lakewater did not support naupliar growth. This can explain the considerable decrease in percentage of the naupliar fraction in lakes with increasing trophy, and thus higher competition from cladocerans (Patalas \& Patalas 1961). This also seemed to be the reason for the marginal habitat selection of nauplii underneath the distribution of cladocerans during sympatric co-occurrence in the plankton (Patalas \& Patalas 1961; Nilssen \& Elgmork 1977; Nilssen 1977; Nilssen 1978). Santer \& Lampert (1995) further found that development of C. abyssorum was retarded and that nauplii of two other Cyclops species died before they reached the first copepodid stage. They (Santer \& Lampert 1995) were also able to culture the animals in the laboratory without an intervening diapause, as observed in the field. Hansen \& Santer (1995) found that naupliar development time of $M$. leuckarti was inversely related to attractive food concentration. The competition between larval (nauplii) stages of cyclopoid copepods and cladocerans may explain the apparent paradoxical, early findings by Parker 
(1960; 1961), that even predaceous and omnivorous copepods can be eliminated by herbivorous cladocerans through competition in early development stages of the copepods. Furthermore, it can also explain why $M$. leuckarti had difficulty establishing large populations in sewage-contaminated ponds when Daphnia magna dominated (Källqvist et al. 1996).

Vijverberg (1980) and Herzig (1983) have shown that both $M$. leuckarti and T. oithonoides are warm-water species; they develop comparably slower at low and more rapidly at high temperatures. $M$. leuckarti is an even more characteristic warm-water species than $T$. oithonoides. Accordingly, Smyly (1974) found that $M$. leuckarti developed very slowly at $4{ }^{\circ} \mathrm{C}$ with high egg mortality. Kiefer (1978) reported for M. leuckarti that eggs did not develop below $6{ }^{\circ} \mathrm{C}$ and that nauplii stagnated at a temperature below $8{ }^{\circ} \mathrm{C}$. Jamieson (1980) was unable to hatch eggs at $6^{\circ} \mathrm{C}$ and nauplii lowered to this temperature promptly died (probably another $\mathrm{Me}$ socyclops species). Herzig (1983) indicated a genetic component in the embryonic development of M. leuc$k a r t i$, but all populations developed rapidly at temperatures above $18^{\circ} \mathrm{C}$.

Cyclopoid copepods with their eleven larval and juvenile stages exhibit developmental or ontogenetical bottlenecks because of competition with specialised filter feeders at specific times of the year. A serious bottleneck possibly takes place after consumption of their yolk-supply, at approximately naupliar 2 stage, when the earlier naupliar stages have to start collecting their own food. Another susceptible stage is the conspicuous metamorphosis prior to copepodid I (see Twombly 1993; 1995), when a new way of collecting food must be initiated. Cladocerans during summer tend to displace the earlier ontogenetical stages of cyclopoid copepods to marginal habitats, often below the thermocline, or the specific cohort dies out altogether due to starvation. The frequent high death rate and/or variable death rates often found in pelagic copepods may be due to this serious competition. One strategy for the cyclopoid would be to suppress early spring growth of cladocerans by consuming juvenile cladocerans (Lampert \& Schober 1978; Nilssen 1978; Santer 1993).

\subsection{Life cycle and habitat selection of adult $\mathrm{M}$. leuckarti in littoral and profundal environments}

Already in 1863, Sars (1863) observed the main ecological differences between the two species, notably the ability of $M$. leuckarti to inhabit small ponds and ditches, in addition to lakes, and mentioned T. oithonoides as a true planktonic form. A number of other authors have later supported this view, and extended the habitat range of $M$. leuckarti to the littoral zone as well (Sramek-Husek 1948; Sladecek 1950; Straskraba 1963; Vranovsky 1964; Flössner 1967; Szlauer 1969; Mäemets \& Haberman 1971; Zawislak \& Bittel 1971; Eie 1974; Forro \& Metz 1987; Vuille 1991; Spikkeland
1998). Litynski (1938) called M. leuckarti therefore an hemilimnetic form. Other authors have reported that $M$. leuckarti can occupy the near sediment region in large parts of lakes as well, not only the macrophyte-dominated littoral. For this reason, Sirkova \& MordukajBoltovski (1971) considered M. leuckarti as a member of the microbenthos, and it was one of the most important microbenthos species in all of several investigated lakes. Comita (1972) observed no planktonic adult females in the population of $M$. edax that appeared after the first of August. He (Comita 1972) ascribed this to their benthic habitat selection after that period, a spatial distribution also observed in other populations of the species (Moore 1939; Cole 1955; Carter 1974; Threlkeld \& Dirnberger 1986). Other studies have stressed the benthic attraction of $M$. leuckarti (Vijverberg \& Richter 1982; Papinska 1984), which may have serious consequences for many life history studies. By overlooking a part of the female population, both the egg stock and birth rates are underestimated, and the mortality rates of the adults overestimated.

In many investigations, adult females, often with eggs, were distributed close to the bottom (Vijverberg \& Richter 1982), or in the littoral zone (Einsle 1972; Sandøy \& Nilssen 1987; Jann \& Bürgi 1988; Elgmork et al. 1990), especially in smaller bodies of water or localities with extensively developed littoral areas. In larger lakes without littoral or profundal refuges, or lakes with very low fish predation, adult females are present in the plankton and the sex ratio is on average close to unity (Ravera 1955; Larsen 1982). Einsle (1964b) seemed to have been the first to describe in detail this widespread phenomenon of planktonic disappearance of adult $M$. leuckarti females. He (Einsle 1964b) mentioned that after $M$. leuckarti terminated diapause and was present with copepodid $\mathrm{V}$ in the free waters, one should have expected a large number of adult females in the waters, but: "Ihre Zahl geht mit dem Anstieg der Erwachsenenkurve bis auf Null zurück(!)" ("The numbers went down to zero when adults should appear"). Shortly thereafter, Einsle (1970) reported the same observation in another lake, and eventually in his 1972 paper (Einsle 1972), he recorded the adult females in the littoral zone, but did not seem to be aware of the ecological importance of these findings. Later, a number of other authors have expressed difficulties to collect sufficient egg-bearing females in population studies of M. leuckarti (Sandøy 1984; Elgmork et al. 1990, Nilssen \& Wærvågen, unpubl. observations 1979-1985).

This conspicuous habitat shift of adult females seems to be a common phenomenon. The reason for this may be several. Adult females with eggs are very susceptible prey for fish (see discussion under predation). To avoid or decrease this predation, adult females select the littoral area or regions close to the bottom as their preferred habitat. Additionally, and just as important, the littoral and profundal areas offer a variety of prey 
species for invertebrate predators, like the predaceous adult females of $M$. leuckarti (body length 1.0-1.3 mm). These findings underscore the importance of sampling several environments, especially the sediment and littoral regions, in life history studies of many cyclopoid copepods. The above described behaviour could also be a strategy to reduce interspecific competition with other species through spatial niche segregation. It should be noted, however, that this habitat selection is not found in all types of lakes. In deeper lakes, with steep littoral zones or reduced macrophyte regions without shelter for predation, adult females with egg sacs are also present in the free waters, and the sex ratio here can be close to unity. Also, in some shallow lakes, like Võrtsjärv, Estonia, which can be considered as an extended littoral zone, females with eggs are also present in large numbers in the plankton, and sex ratio is close to unity (Schönberg 1961). Other species of Mesocyclops (e.g. M. edax) can also use the anoxic hypolimnion as a refuge for visual fish predation (Williamson \& Magnien 1982). Other predation-vulnerable copepods, like Heterocope saliens can also aggregate in the littoral zone to avoid predation from pelagic fish species (Andersen \& Nilssen 1984).

Smyly (1962), in his careful study on cop V of $M$. leuckarti, detected differences concerning many dormancy factors in two populations: dormancy differed throughout the season (see also Elgmork \& Nilssen 1977), and it could be prevented altogether if the animals were offered ample food in the laboratory well before diapause.

\subsection{Reproductive parameters: number and size of offspring}

Number and size of offspring are important parameters in life history studies. Egg size and nauplius size are positively related (Cooney \& Gehrs 1980). The general theory is, the larger the egg size (more energy allocated by adult females to single eggs), the greater changes there will be to overcome developmental bottlenecks, like these resulting from competition by filter feeding cladocerans. Burns (1988) found that egg size per se was not a good predictor of the relative abilities of the nauplii of different copepods to resist starvation, but that small clutches are composed of higher quality eggs than large clutches are. Differences in egg quality, as reflected in naupliar survival, may arise from differences among species in the composition of the stored reserves, which may also vary seasonally (Burns 1988).

Studies on such important life history parameters as above are remarkably rare with plankton animals (see Hutchinson 1951; 1967), but the early work of Czeczuga (1960) is a notable and classical exception. Czeczuga (1960) analysed numbers and size of eggs of a number of planktonic species of differing food patterns in 4 lakes of different nutrient levels. A number of interesting questions arise from his analysis, in addition to those already commented upon by Hutchinson (1967). It seemed that $M$. leuckarti and T. oithonoides were using all available food during the spring outburst of algae, that is often dominated by attractive flagellates as food items (Santer \& Lampert 1995), because egg numbers in spring animals did not increase even when conditions were getting more eutrophic. The size of the spring animals was also comparable throughout the trophic gradient. The summer situation was completely different. The animals were smaller, probably due to ontogenetical competition from cladocerans, and number of eggs were fewer, but they were generally larger; that was probably a strategy to allocate more energy to each single offspring, to decrease a possible effect of food bottleneck during summer. However, a predation effect was most probably also included, since egg carrying $M$. leuckarti are very susceptible to predation (see Fig. 2; and predation part). The smaller $T$. oithonoides, on the other hand, often seems outside the range of most fish predators (except for underyearlings), because nearly all cladocerans are more conspicuous prey than this species. The reproductive effort, as egg biomass in relation to body weight, increased for $T$. oithonoides, both in spring and summer cohorts, whereas no clear picture was evident for the predation vulnerable M. leuckarti, neither in the spring nor summer cohorts (Czeczuga 1960). Egg volumes in T. oithonoides were much higher in the spring cohorts compared with the summer cohorts. They were stable in the spring cohorts with increasing trophy, but increased in the summer cohorts with increasing trophy. For M. leuckarti the picture was less clear. Egg volumes of the spring cohorts decreased with eutrophication as in the summer cohorts. These findings may also indicate a different food saturation curve or different habitat distribution for nauplii of the two species. Clutch sizes of $M$. leuckarti was usually 20-35 eggs per ovigorous female and 6-20 for T. oithonoides (Czeczuga 1960; these numbers were similar to data in figure 7).

The evolutionary consequences of the above findings seem to be that during spring, non-predation vulnerable animals appear to be saturated with food (based on stable specific body size at that time), and more food does not lead either to larger animals, nor larger and more eggs. It should be added, however, that the spring animals partly subsist on food collected during late summer and autumn the previous year. In addition, diapause involves complex chemical and metabolic transformations within the animals' body, likely to influence the subsequent reproduction after a dormancy period. The prehistory of the spring animals is therefore important to study. The predation-vulnerable species, on the other hand, does not seem to grow larger under eutrophic conditions. Furthermore, it also allocates less energy for each single egg, maybe because food is always in access for their offspring under the more eutrophic environments. 


\subsection{M. leuckarti and $\mathrm{T}$. oithonoides as predators and prey}

Already in 1954, Patalas (1954b) stated that the biomass and yearly production of Crustacea should be considered as the remainder after satisfying the food requirements of the fish, both the underyearlings and adult fish (see also Bittel 1964). The cyclopoid copepods, especially the larger-sized species and/or those in late ontogenetical stages, are also vulnerable for fish predation, and many animals must adapt their life histories to this seasonal population stress (see extended discussion in Nilssen 1977; 1980a). Females of medium-sized cyclopoids, like M. leuckarti, when carrying large eggs sacs, are especially vulnerable to fish predation (see also Gliwicz 1967; Gliwicz \& Rowan 1984). The egg sacs of $M$. leuckarti protrude from the genital segment in a characteristic manner (see drawing in Sars 1918; reproduced in figure 2, this paper). Such broad egg sacs offer much frictional resistance in the water, especially during periods with larger clutches (see Maier 1994). T. oithonoides has much smaller clutches than the former (Fig. 7). Even if $T$. oithonoides is a smaller-sized animal, it may be more mobile and more successful in escaping a predator. Therefore, it is not unexpected that M. leuckarti has developed additional strategies to reduce the mortality of eggbearing females, such as staying in the littoral, profundal or oxygen boundary regions where fish are either absent or experience hunting difficulties. Papinska (1985) demonstrated that the species utilise detrital food. It should be added that $M$. leuckarti adult females also seemed more predacious towards animal food than many other cyclopopid species (Hansen \& Santer 1995; Hopp et al. 1997). The littoral areas offer a variety of animal food items and thus may be an additional habitat to a plankton-littoral species like M. leuckarti.

Hrbacek \& Novotna-Dvorakova (1965) remarked that $M$. leuckarti was more frequently observed when fish stock decreased in four manipulated backwaters, especially when compared with Thermocyclops species, $T$. oithonoides and T. crassus. Studies on the relationships between the abundance, life cycles and life histories of cyclopoid copepods and fish are remarkably rare. This may partly be due to the fact that many papers maintain that "fish" (at summer sampling periods and above $20 \mathrm{~cm}$ body length) mainly consume cladocerans and benthos, and cyclopoid copepods are considered unimportant food items. Nevertheless, we hypothesise that the numerical suppression of $M$. leuckarti, the sex ratio, the habitat distribution of adult females, and the life cycles in many eutrophic lakes, is mainly an effect of fish predation, and $0^{+}$fish should be especially investigated with respect to this (see Guma'a 1977; Hansen \& Jeppesen 1992). Adult planktivorous fish usually select cladoceran prey (see Nilssen 1977; 1978; Sanni \& Wærvågen 1990), but $0^{+}$fish select a variety of prey, from algae and rotifers to cladocerans and copepods.
Especially the young fish may exert a considerable influence upon copepod abundance. Usually the largest copepods are the first to be selected, especially females with eggs (Langeland 1982). Podboltova \& Potapova (1972) found that both $M$. leuckarti and T. oithonoides were consumed by fish, but $M$. leuckarti was more strongly selected than the smaller species by the vendace (Coregonus albula). Accordingly, Spanovskaja \& Grygorash (1977) found that adult $M$. leuckarti was selected as planktivorous fish food, together with Daphnia longispina and D. cucullata. Nauplii and copepodid stages were not consumed (Spanovskaja \& Grygorash 1977).

There will be a cost associated with producing large clutches of eggs in the presence of fish predation (Winfried \& Townsend 1983; Vourinen et al. 1983; Hairston et al. 1983), especially in medium-sized copepods, like $M$. leuckarti. The large egg sacs of M. leuckarti in eutrophic lakes decrease the maneuverability of females (Winfried \& Townsend 1983), and their success in such lakes is therefore considerably reduced when fish predators are abundant. Larger-sized egg-carrying species cannot occupy the epipelagic zone in freshwater, but survive instead by dwelling in the littoral and profundal habitats. Advanced copepodids of M. leuckarti have about a similar size to adult $T$. oithonoides. Therefore non-conspicuous, negligibly coloured and pigmented adult $T$. oithonoides of $0.7-0.8 \mathrm{~mm}$ total length may be outside the prey range for most fish species. They may be consumed by $0^{+}$fish (perch and roach), if they are forced to coexist in the same habitat, as observed in small enclosures (Ø $1.5 \mathrm{~m}, 4 \mathrm{~m}$ deep) sealed at the bottom (Hessen 1982).

Smyly (1980) reported a specific relationship between the invertebrate predator Chaoborus flavicans and the two cyclopoids, C. abyssorum and M. leuckarti. In tests with the two interacting cyclopoids, $C$. abyssorum outcompeted $M$. leuckarti when Chaoborus was absent but lost to M. leuckarti when Chaoborus was present. Smyly (1980) ascribed this to the swimming patterns of the two species; the "continuous" swimmer $C$. abyssorum was more conspicuous prey for Chaoborus than $M$. leuckarti, which in accordance with its more littoral-pelagic habitat distribution, interspersed short bouts of swimming with long periods of clinging to interfaces.

The most important food for Mesocyclops and Thermocyclops are rotifers and cladocerans, especially for the younger stages of the latter (Monakov \& Sorokin 1959; Brandl \& Fernando 1975; 1986; Karabin 1978; Williamson 1980; Papinska 1985). Monakov \& Sorokin (1959) and Brandl \& Fernando (1979) reported that juveniles of the plankton-littoral species Diaphanosoma (see Herzig 1984) and genus Ceriodaphnia were important food for advanced stages of Mesocyclops, and the same was found in Lake Kinneret (Gophen 1977) and Lake Donghu (Yufeng 1998). Fryer (1957a; 1957b) 
has investigated the food collection mechanisms and food selection behaviour exhibited by several species of cyclopoid copepods. Fryer (1957a) claimed that $M$. leuckarti chiefly consumed crustaceans and rotifers. In this study, Fryer (1957a) lumped two species of $\mathrm{Me}$ socyclops together; M. leuckarti from Loch Lomond and probably $M$. aequatorialis from Lake Nyasa. Smyly (1961) made some casual observations and found that M. leuckarti consumed young Eudiaptomus gracilis, $D$. brachyurum and D. hyalina in Esthwaite Water.

Usually, smaller-sized cyclopoids are less carnivorous than larger ones within the same biotop (Hopp et al. 1997; Brandl 1998). M. leuckarti seems to be more carnivorous than expected solely based on body size (Hansen \& Santer 1995; Hopp et al. 1997), and even its smaller copepodids seem more carnivorous than similarsized or even larger cyclopoids (Hansen \& Santer 1995). M. leuckarti needed animal food to produce a high number of viable offspring (Hansen \& Santer 1995; Hopp et al. 1997). This may partly be due to the temporal presence of the species, since it is present and reproduces during summer when algae is scarce or inedible and when protozoans, nauplii and rotifers are abundant. On the other hand, Thermocyclops spp. can do well on algae alone (Adrian \& Frost 1993; Hopp et al. 1997), even if $T$. oithonoides has been reported to consume a lot of protozoans (Monakov 1972). Also when offered a dinoflagellate as food, T. oithonoides showed more "sloppy feeding" (killed the prey, but did not ingest it all) than M. leuckarti did (Santer 1996). Usually, when the two species coexist in the plankton the size relationship between $M$. leuckarti and T. oithonoides is 1.3 or more, a size difference that has been shown to facilitate coexistence in nearby species (see Hutchinson 1967).

\subsection{Diapause and wintering}

Diapause is a strategy for avoiding harmful conditions and synchronizing growth and reproduction with favourable biotic and abtiotic conditions in time and space. It is also a period for seasonal reduction of activity and for considerable restructuring of internal body biochemistry, morphology and anatomy. Transition of stored energy, most often triacylglycerol, in freshwater copepods (see Wierzbicka \& Kenzierski 1970; Sargent 1978; Santer \& Bolt 1998), may provide those copepods which spend late juvenile stages in diapause with readily available energy reserves for the deposition of several clutches of eggs after reproduction immediately following diapause termination.

Resting can take place in both cop. IV and V, the relative proportions between the two differs in the various investigations. Smyly (1968) found that less than $15 \%$ of the dormant population was in stage IV in British lakes, and both Nauwerck (1963) in Lake Erken and Szlauer (1963) in Stary Dwor Lake found stage V to be dominant. Elgmork (1964), on the other hand, found more than $50 \%$ in cop. IV in small ponds in east-central Norway, and in Loch Lomond Chapman (1972) found around $40 \%$ cop. IV. The composition of animals in dormancy probably depends upon developmental patterns and ambient temperature in the habitat. It could also be a strategy to decrease competition by timing the life cycle for nauplii to avoid being predated by adults of other cyclopoid species, or to be present at maximum food availability during algal spring peak.

Wierzbicka (1974) observed that the freezing point depression (probably related to body triacylglycerol levels) of several species of diapausing cyclopoids was must higher than for active planktonic animals. Wierzbicka \& Kedzierski $(1964 ; 1970)$ also found that diapausing animals could withstand considerable anoxia and that they accumulated both oil and metabolic products (Wierzbicka 1972). Wierzbicka (1962) investigated the attraction of cyclopoid copepods of the genus Cyclops to the mud surface. All species used the sediment for feeding and burrowing and when it was removed they moulted and became adult. Their swimming feet were used to burrow, and could as well be described as "swimming and burrowing" feet (Wierzbicka 1962); the larger the species, the deeper it could penetrate into the mud.

In the majority of the investigated localities, both $M$. leuckarti and $T$. oithonoides disappeared from the plankton during winter. This seemed to be a more consistant life history trait in northern and high altitude lakes. Both species are mainly lowland and epilimnetic species. Even if wintering in sediment habitats is the most frequently reported form of diapause, alternative development paths are possible, but their evolutionary strategies remain unclear. The following summarises the observed patterns of wintering for the two species:

A. The whole population diapauses in the sediment as cop. IV and/or cop. V. The relationship between the two stages depends upon the speed of development in the plankton and age of the specimens prior to dormancy, affected by a combination of temperature and food (most northern and eastern populations, shallow lakes on the continental Europe).

B. As A above, but with a minor fraction of the population overwintering in the plankton, in "active diapause" (several northern and eastern populations; $T$. oithonoides in Lake Créteil). A greater tendency for "active diapause" (or plankton diapause) is observed in T. oithonoides compared with M. leuckarti in their area of overlap.

C. As A or B above, M. leuckarti is the first species of the two to diapause and the last to migrate into the plankton in spring (the majority of northern lakes); as A or B above, T. oithonoides is the first species to diapause and last to enter plankton in spring (some Polish populations); as A or B above, the two species diapause and enter plankton simultaneously (several Polish and Norwegian populations). 
D. A large part of the species populations of either $M$. leuckarti or $T$. oithonoides overwinter in the plankton in "active diapause" as well as in the sediments (Bodensee, Lake Biel (= Lac Neuchâtel), Loch Lomond).

E. The entire population of either $M$. leuckarti or $T$. oithonoides overwinters solely in the plankton in "active diapause", in mainly copepodid IV and V stages, without any conspicuous ontogenetic development (Obersee (upper Bodensee), Attersee, Viervaldstättersee, some Russian sites).

F. The whole population overwinters in the plankton, but develops slowly during winter (Lago Maggiore).

The different observations concerning bathyographic habitat selection of diapause is difficult to explain in evolutionary terms at the present state of knowledge (Nilssen \& Østdahl in prep.), but the time of spring revival in the plankton may partly be ascribed to temperature conditions at the selected diapause site. Fig. 6 shows the observations of different diapause habitats utilised by selected populations of $M$. leuckarti and $T$. oithonoides. In many cases, but not all, both species selected the more shallow part of the lake. However, in shallow lakes, the species often selected the deepest part. In deeper lakes, $M$. leuckarti selected more shallow areas, at a depth of only 0.5-2 meters. Littoral sites, as shallow ponds and lakes, follow more closely ambient air temperatures throughout the year. Gieysztor (1960) made a detailed study of this phenomenon, also involving diurnal measurements during different times of the year. Littoral areas, especially strata where M. leuckarti frequently diapause (Fig. 6), are subjected to much higher temperatures during spring conditions (up to 10 ${ }^{\circ} \mathrm{C}$ higher than in the pelagic epilimnion is common). High temperatures lead to earlier revival from diapause (Maier 1989, 1990).

We therefore hypothesise that in lakes where $M$. leuckarti is diapausing at shallow depths in the littoral zone (at 0.5-1.5 $\mathrm{m}$ depth), and T. oithonoides in the deepest region, $M$. leuckarti should have a selective time advantage over $T$. oithonoides, by exhibiting earlier diapause revival and faster ontogenetic development during spring. The greater the difference between the dormancy habitat temperature of the two species is, the greater the difference in diapause termination during spring will be. The time of spring arousal may also influence the time of the initiation of diapause in autumn, the relationship between cop. IV and cop. V in diapause, and the number of cohorts that can be produced during the pelagic phase.

Habitat selection of diapause may also be influenced by prey availability in any given specific part of the lake. Several species of cladocerans distribute their resting eggs in the littoral as well, like D. brachyurum (see Herzig 1984) and Bosmina longispina. Both cladocerans terminate egg diapause at times comparable to the carnivorous late copepodids of M. leuckarti. The latter thus have attractive prey with small body sizes available at a critical time during its ontogenetical development.

\section{CONCLUSIONS}

When superficially studied, M. leuckarti and $T$. oithonoides, among the most common European species of cyclopoid copepods, share a lot of common characteristics: body shape, diapause periods, presence in the plankton, geographical distribution, habitat selection, ontogenetic development patterns, and depth distribution. Nevertheless, a whole array of ecological differences exist between the two species, including these presented in this paper:

- The habitat of M. leuckarti is characteristically both littoral/profundal and planktonic, whereas $T$. oithonoides is a true planktonic species.

- M. leuckarti is considerably larger than T. oithonoides; total body length $1.0-1.3 \mathrm{~mm}$ vs $0.7-1.0$, respectively.

- The negligibly coloured and smaller adult $T$. oithonoides may be outside the prey range for many fish species.

- Egg sacs of the larger species M. leuckarti protrude from its genital segment, likely increasing water friction.

- The numerical suppression of $M$. leuckarti, its sex ratio, the habitat distribution of adult females, and its life cycles in many eutrophic lakes, is probably strongly affected by fish predation.

- M. leuckarti has probably developed strategies to reduce predation on eggbearing females, such as staying in littoral, profundal or oxygen boundary regions where fish are either absent or experience hunting difficulties.

- In its northern range, M. leuckarti showed sediment diapause in all types of localities, even the deepest lakes, usually in the upper littoral region. In more shallow lakes, deeper diapause sites were observed.

- T. oithonoides diapaused in either the lower littoral, or the profundal regions.

- The period of diapause for M. leuckarti (especially in the sediment) decreased from north to south. At about $45^{\circ} \mathrm{N}$, sediment and plankton diapause were non-existent, and the species exhibited continuous development, even with relatively low winter temperatures.

- T. oithonoides, whose southern distribution in western Europe extends to about $50^{\circ} \mathrm{N}$, showed winter sediment diapause throughout its distribution, but frequently with a fraction of the population in plankton diapause.

- M. leuckarti most ptobably arrived prior to T. oithonoides after ice withdrawal from northern Europe, and was found at higher altitudes. 
- In a border distributional region of $T$. oithonoides in southern Norway, the species was found exclusively below the highest postglacial marine limit, whereas it had spread to other neighbouring lakes above the former marine limit close to its more central distributional region in eastern Norway.

\section{ACKNOWLEDGMENTS}

This paper has profited from discussions with a number of zooplanktonologists during the last three decades. We are especially grateful to Bruno Berzins, Uli Einsle, Kåre Elgmork, Alois Herzig and Maria Wierzbicka for early and generous sharing of ideas and unpublished data on taxonomy, ecology and diapause of cyclopoid copepods. We take, however, responsibility for the present synthesis, including any and all mistakes. We are furthermore thankful to Bjørn Walseng and coworkers for permission to use their unpublished figure 3A-B. A special thanks goes to Robert C. Wilson for correcting the English language. Finally, we are grateful to a number of our students for collecting samples and chemical analyses in part of this investigation.

\section{REFERENCES}

Aagaard, K. \& D. Dolmen. 1996. Limnofauna Norwegica. Katalog over norsk ferskvannsfauna. Tapir forl., Trondheim: $310 \mathrm{pp}$ (in Norwegian, summary and introduction in English)

Adrian, R. \& T.M. Frost. 1993. Omnivory in cyclopoid copepods: comparison of algae and invertebrates as food for three, differently sized species. J. Plankton Res., 15: 643658.

Alekseev, V.R. 1987. Photoperiodism and seasonal population dynamics of Mesocyclops leuckarti (Claus)(Crustacea, Copepoda). Gidrobiol. J., 23: 22-28 (in Russian).

Alekseev, V.R. 1991. Diapause of Crustacea: Ecological physiological aspects. Nauka Press, Moscow: 144 pp (in Russian).

Amoros, C. 1973. Évolution des populations de Cladocères et Copépodes dans trois etangs piscicole de la Dombes. Annls limnol., 9: 135-155.

Andersen, R. \& J.P. Nilssen. 1984. Mechanisms of co-existence of Heterocope saliens (Crustacea, Copepoda) and planktivorous fish. Fauna nor., Ser A, 5: 31-36.

Birge, E.A. \& C. Juday. 1908. A summer resting stage in development of Cyclops bicuspidatus Claus. Trans.Wis.Acad.Sci.Arts Lett., 16: 1-9.

Bittel, L. 1964. Rotifers and Crustacea in the plankton of some "perch-pike" lakes. Pol. Arch. Hydrobiol., 22: 265-278.

Bittel, L., S. Grimm \& S. Ochocki. 1965. The horizontal distribution of zooplankton in the southern part of Lake Jeziorak. Zesz. Nauk. UMK, 13, prac. sta. limnol. Ilawie, 1: 21-46.

Bjørndalen, K. \& H. Warendorph. 1982. Vansjø. Hydrografi og plankton $i$ en innsjø med kompleks bassengform. Thesis, Univ. Oslo: 269 pp (Mimeogr. in Norwegian).

Blakar, I. 1978. A simple water and plankton sampler. Freshwat. Biol., 8: 533-537.

Brandl, Z. 1998. Feeding strategies of planktonic cyclopoids in lacustrine ecosystems. J. Mar. Systems, 15: 87-95.

Brabrand, Å., B. Faafeng \& J.P. Nilssen. 1987. Pelagic predators and interfering algae: Stabilizing factors in eutrophic lakes. Arch. Hydrobiol., 110: 533-552.

Brandl, Z. \& C.H. Fernando. 1975. Food consumption and utilization in two freshwater cyclopoid coepods (Mesocy- clops edax and Cyclops vicinus). Int. Revue ges. Hydrobiol., 60: 471-494.

Brandl, Z. \& C.H. Fernando. 1979. The impact of predation by the copepod Mesocyclops edax (Forbes) on zooplankton in three lakes in Ontario, Canada. Can. J. Zool., 57: 940-942.

Brandl, Z. \& C.H. Fernando. 1986. Feeding and food consumption of Mesocyclops edax. Syllogeus, 58: 254-258.

Burns, C.W. 1988. Starving resistance among copepod nauplii and adults. Verh. int. Ver. Limnol., 23: 2087-2091.

Burgis, M.J. 1970. The effect of temperature on the development time of eggs of Thermocyclops sp., a tropical cyclopoid copepod from Lake George, Uganda. Limnol. Oceanogr., 15: 742-747.

Carter, J.C.H. 1974. Life cycles of three limnetic copepods in a beaver pond. J. Fish. Res. Bd Canada, 31: 421-434.

Chapman, M.A. 1972. The annual cycle of the limnetic cyclopoid Copepoda of Loch Lomond, Scotland. Int. Revue ges. Hydrobiol., 57: 895-911.

Czeczuga, B. 1960. Changes in fertility of some representatives of the zooplankton. I. Crustacea from the Rajgrodzkie lakes. Pol. Arch. Hydrobiol., 7: 61-91 (in Polish, summary in English).

Cole, G.A. 1953. Notes on copepod encystment. Ecology, 34: 208-211.

Cole, G.A. 1955. An ecological study of the macrobenthic fauna og two Minnesota lakes. Am. Midl. Nat., 53: 213230.

Comita, G.W. 1972. The seasonal zooplankton cycles, production and transformation of energy in Severson Lake, Minnesota. Arch. Hydrobiol., 70: 14-66.

Cooney, J.D. \& C.W. Gehrs. 1980. The relationship between egg size and naupliar size in the calanoid copepod Diaptomus clavipes Schacht. Limnol. Oceanogr., 25: 549-552.

Dahms, H.-U. \& C.H. Fernando. 1993. Redescriptions of Mesocyclops leuckarti (Copepoda, Cyclopoida), including a study of its naupliar development. Int. Revue ges. Hydrobiol., 78: 589-609.

Demmo, R. 1985. En undersøkelse av zooplanktonsamfunnene $i$ Bosvikkilen. En limnisk og en marin lokalitet ved Risør $i$ Aust-Agder. Thesis, Univ. Oslo: 202 pp (Mimeogr. in Norwegian).

Dussart, B.H. \& C.H. Fernando. 1986. The Mesocyclops species problem today. Syllogeus, 58: 288-293.

Eie, J.A. 1974. A comparative study of the crustacean communities in forest and mountain localities in the Vassfaret area (southern Norway). Norw. J. Zool., 22: 177-205.

Einsle, U. 1964a. Die Gattung Mesocyclops im Bodensee. Arch. Hydrobiol., 60: 133-199.

Einsle, U. 1964b. Das Crustaceenplankton des Mindelsees. Beitr. naturk. Forsch. SW-Deutschl., 23: 53-70.

Einsle, U. 1969a. Populationsdynamiche und synökologische Studien am Crustaceen-Plankton zweier Kleinseen. Beitr. naturk. Forsch. SW-Deutschl., 28: 53-73.

Einsle, U. 1969b. Untersuchungen zur Vertikalwanderung planktischer Crustaceeen im Bodensee-Obersee. Schr. Ver. Gesch. Bodensee Umgebg., 87: 177-187.

Einsle, U. 1970. Weitere Ergebnisse limnologischer Untersuchungen an der Buchenseen (bei Radolfzell/Bodensee). Veröff. Landestelle f. Naturschutz u. Landschaftsplege Baden-Württemberg, 38: 95-112.

Einsle, U. 1972. Die räumliche Verteilung einiger pelagisch lebender Crustaceen im Litoral des Mindelsees. Schr. Ver. Gesch. Bodensee Umgebg., 90: 259-269.

Einsle, U. 1975. Revision der Gattung Cyclops s. str., speziell der abyssorum-gruppe. Mem. Ist. ital. Idrobiol., 32: 57219.

Einsle, U. 1983. Long-term changes in planktonic associations of crustaceans in Lake Constance and adjacent waters and their effects on competition situations. Hydrobiologia, 106: $127-134$. 
Einsle, U. 1987. Zur Vertikalwanderung planktischer Copepoden im Bodensee-Obersee. Schweiz. Z. Hydrol., 49: 303315 .

Einsle, U. 1988. The long-term dynamics of crustacean communities in Lake Constance (Obersee, 1962-1986). Schweiz. Z. Hydrol., 50: 136-165.

Einsle, U. 1989. The identification of copepodid instar of some calanoid and cyclopoid copepods of Lake Konstanz, Federal Republic of Germany. Crustaceana, 57: 79-87.

Elgmork, K. 1958. On the phenology of Mesocyclops oithonoides (G.O. Sars). Verh. int. Ver. Limnol., 13: 778784

Elgmork, K. 1964. Dynamics of zooplankton communities in some small inundated ponds. Folia Limnol. Scand., 12: 183.

Elgmork, K. 1973. Bottom resting stages of planktonic cyclopoid copepods in meromictic lakes. Verh. int. Ver. Limnol., 18: 1474-1478.

Elgmork, K. 1996. Variation in torpidity of diapause in freshwater cyclopoid copepods. Hydrobiologia, 320: 63-70.

Elgmork, K. \& J.P. Nilssen. 1978. Equivalence of copepod and insect diapause. Verh. int. Ver. Limnol., 20: 25112517.

Elgmork, K., G. Halvorsen, J.A. Eie \& A. Langeland. 1990. Coexistence with similar life cycles in two species of freshwater copepods (Crustacea). Hydrobiologia, 208: 187-199.

Faafeng, B. \& J.P. Nilssen. 1981. A twenty-year study of eutrophication in a deep, soft-water lake. Verh. int. Ver. Limnol., 21: 412-424.

Flössner, D. 1967. Beitrag zur Kenntnis der Cladoceren- und Copepodenfauna des Donaudeltas. Limnologia (Berlin), 5: 223-250.

Forro, L. \& H. Metz. 1987. Observations on the zooplankton in the reedbelt area of the Neusiedlersee. Hydrobiologia, 145: 299-307.

Frenzel, P. 1977. Zur Bionomie von Thermocyclops oithonoides (G.O. Sars). Arch. Hydrobiol., 80: 108-130.

Frey, D.G. 1980. On the plurality of Chydorus sphaericus (O.F. Müller), and designation of a neotype from Sjaelso, Denmark. Hydrobiologia, 69: 83-123.

Frey, D. G. 1982. Cosmopolitanism in Cladocera. Arch. Hydrobiol., 93: 484-502.

Fryer, G. 1957a. The food of some freshwater cyclopoid copepods and its ecological significance. J. Anim. Ecol., 26: 263-286.

Fryer, G. 1957b. The feeding mechanism of some freshwater cyclopoid copepods. Proc. zool. Soc. Lond., 129/part 1: 125.

Fryer, G. 1993. The freshwater Crustacea of Yorkshire. A faunistic \& ecological survey. Yorkshire naturalist union \& Leeds philosophical and literary society. Titus Wilson and Son, Kendal, Cumbria: $312 \mathrm{pp}$.

Fryer, G. \& W.J.P. Smyly. 1954. Some remarks on the resting stages of some freshwater cyclopoid and harpacticoid copepods. Ann. Mag. Nat. Hist., 12(7): 65-72.

Gieysztor, M. 1959. On a continuous series of lakes. Pol. Arch. Hydrobiol., 6: 175-187.

Gieysztor, M. 1960. On the thermal conditions of the littoral zone of lakes. Pol. Arch. Hydrobiol., 7: 171-193.

Gliwicz, Z.M. 1967. Zooplankton and temperature-oxygen conditions of two alpine lakes of the Tatra Mountains. Pol. Arch. Hydrobiol., 14: 53-72.

Gliwicz, Z.M. \& M.G. Rowan. 1984. Survival of Cyclops abyssorum tatricus (Copepoda, Crustacea) in alpine lakes stocked with planktivorous fish. Limnol. Oceanogr., 29: 1290-1299.

Gophen, M. 1977. Food and feeding habits of Mesocyclops leuckarti (Claus) in Lake Kinneret (Israel). Freshwat. Biol., 7: 513-518.
Gophen, M. 1986. Mesocyclops and Thermocyclops populations in Lake Kinneret (Israel). Syllogeus, 58: 294-299.

Gophen, M. 1988. Changes of Copepoda populations in Lake Kinneret during 1969-1985. Hydrobiologia, 167/168: 375379 .

Granberg, K. 1970. Seasonal fluctuations in numbers and biomass of the plankton of Lake Pääjärvi, southern Finland. Ann. Zool. Fennici, 7: 1-24.

Guma'a, S.A. 1978. The food and feeding habits of young perch, Perca fluviatilis, in Lake Windermere. Freshwat. Biol., 8: 177-187.

Gurney, R. 1931-1933. British Freshwater Copepoda. Vol. IIII. Ray Soc. London.

Guttowa, A. 1956. Research on salty waters in Poland. Research on plankton in the Lebsko and Sarbsko lakes. Pol. Arch. Hydrobiol., 3: 269-290.

Hairston, N.G.jr, W.E. Walton \& K.T. Li. 1983. The causes and consequences of sex-specific mortality in a freshwater copepod. Limnol. Oceanogr., 28: 935-947.

Hajduk, Z. 1966. The fauna of Cladocera and Copepoda-Cyclopoida in water basins of the quarries of Strzeblow. Acta Univ. Wratislaviensis, 51, prac.zool. 2: 125-152.

Hakkari, L. 1969. Zooplankton studies in the Lake Längelmävesi, south Finland. Ann. Zool. Fennici, 6: 313-326.

Halme, E. 1958. Planktologische Untersuchungen in der PojoBucht und angrenzenden Gewässer. Ann. Zool. Soc. Vanamo, 19: 1-62.

Halvorsen, G. \& Elgmork. 1976. Vertical distribution and seasonal cycle of Cyclops scutifer Sars (Crustacea, Copepoda) in two oligotrophic lakes in southern Norway. Norw. J. Zool., 24: 143-160.

Halvorsen, G. \& D.A. Larsen. 1998. Ferskvannsbiologiske undersøkelser i Vegårvassdraget. NINA-oppdragsmelding, 520: 1-29 (in Norwegian, tabels, figures and summary in English).

Halvorsen, G., S.-E. Sloreid \& B. Walseng. 1993. The Dokka delta - consequences of water power development in the River Dokka. NINA forskningsrapport, 437: 1-101 (in Norwegian, tabels, figures and summary in English).

Hansen, A.-M. \& E. Jeppesen. 1992. Changes in the abundance and composition of cyclopoid copepods following fish manipulations in eutrophic Lake Væng, Denmark. Freshwat. Biol., 28: 183-193.

Hansen, A.-M. \& B. Santer. 1995. The influence of food resources on the development, survival and reproduction of the two cyclopoid copepods: Cyclops vicinus and Mesocyclops leuckarti. J. Plankton Res., 17: 631-646.

Herbst, H.V. 1951. Ökologische Untersuchungen über die Crustaceenfauna südschleswigscher Kleingewässer mit besonderer Berücksichtigung der Copepoden. Arch. Hydrobiol., 45: 413-542.

Herbst, H.V. 1955. Untersuchung zur quantitativen Verteilung des Zooplanktons im Grossen Plöner See. Arch. Hydrobiol., 50: 234-290.

Herzig, A. 1983. The ecological significance of the relationship between temperature and duration of embryonic development in planktonic freshwater copepods. Hydrobiologia, 100: 65-91.

Herzig, A. 1984. Temperature and life cycle strategies of Diaphanosoma brachyurum: An experimental study on development, growth, and survival. Arch. Hydrobiol., 101: 143-178.

Hessen, D.O. 1982. Eksperimentelle innhegningsforsøk $i$ Gjersjøen med spesiell vekt på zooplanktonets relasjon til fytoplankton, bakterier og planktivor fisk. Thesis, Univ. Oslo: 141pp (Mimeogr. in Norwegian).

Hessen, D.O. \& J.P. Nilssen. 1983. High $\mathrm{pH}$ and the abundance of two commonly co-occurring freshwater copepods (Copepoda, Cyclopoida). Annls Limnol., 19: 195-201. 
Hobæk, A. \& G.G. Raddum. 1980. Zooplankton communities in acidified lakes in South Norway. SNSF-project, IR 75/80: 1-132.

Hopp, U., G. Maier \& R. Bleher. 1997. Reproduction and adult longevity of five species of planktonic cyclopoid copepods reared on different diets: a comparative study. Freshwat. Biol., 38: 289-300.

Hrbacek, J. \& M. Novotna-Dvorakova. 1965. Plankton of four backwaters related to their size and fish stock. Rozpravy $C Z A V$, rada $M P V, 75,13: 1-65$.

Huitfeldt-Kaas, H. 1924. Einwandrung und Verbreitung der Süsswasserfische in Norwegen mit einen Anhanh über den Krebs. Arch. Hydrobiol., 14: 223-214.

Hutchinson, G.E. 1951. Copepodology for the ornitologist. Ecology, 32: 571-577.

Hutchinson, G.E. 1967. A treatise on limnology. Volume II. Introduction to lake biology and the limnoplankton. John Wiley \& Sons, NY: $1115 \mathrm{pp}$.

Huys, R. \& G.A. Boxshall. 1991. Copepod evolution. The Ray Society, London: 468pp.

Jamieson, C. 1980. Observations on the effect of diet and temperature on rate of development of Mesocyclops leuckarti (Claus)(Copepoda, Cyclopoida). Crustaceana, 38: 145154

Jann, B. \& H. Bürgi. 1988. The drift of zooplankton in a lakeoutlet (Glatt) in a day-night-rhythm depending from the water level. Schweiz. Z. Hydrol., 50: 87-95.

Jørgensen, I. 1972. Forandringer i strukturen til planktoniske og littorale Crustacea-samfunn under gjengroing av humusvann i området Nordmarka og Krokskogen ved Oslo, korrelert med hydrografiske data. Thesis, Univ.Oslo, $107 \mathrm{pp}$. (Mimeogr. in Norwegian).

Källqvist, T., S. Markager, A. Erlandsen, J.E. Løvik \& L. Lien. 1996. Resirkulering av næringssalter i biodammer med alger og dafnier. NIVA-Rapport, 3563/96: 1-83 (in Norwegian, summary in English).

Kajak, Z. 1971. Benthos of standing water. In: W.T. Edmondson \& G.G. Winberg (Eds), A manual on methods for the assessment of secondary productivity in fresh waters. IBP Handbook no. 17, Blackwell Sci. Publs., Oxford, 25-65.

Karabin, A. 1978. The pressure of pelagic predators of the genus Mesocyclops (Copepoda, Crustacea) on small zooplankton. Ekol. pol., 26: 241-257.

Karabin, A. 1983. Ecological characteristics of lakes in northeastern Poland versus their trophic gradient. VII. Variations in the quantitative structure of the pelagic zooplankton (Rotatoria and Crustacea) in 42 lakes. Ekol. pol., 31: 383-409.

Kasprzak, P. \& W. Schwabe. 1987. Some observations on the diurnal vertical migration of crustacean zooplankton in a stratefied oligotrophic clear water lake (Lake Stechlin, GDR). Limnologica (Berl.), 18: 297-311.

Kiefer, F. 1927. Versuch eines Systems der Cyclopiden. Zool. Anz., 73 (11/12): 302-308.

Kiefer, F. 1928. Über Morphologie und Systematik der freilebenden Süsswasser Cyclopoiden. Z. wiss. Zool., 133: 1-56.

Kiefer, F. 1952. Copepoda Calanoida und Cyclopoida. In: Exploration du Parc National Albert, Mission H. Damas (1935-1936)., fasc. 21: 1-136.

Kiefer, F. 1978. Freilebende Copepoda. Die Binnengewässer, 26/2: 1-343.

Kiefer, F. 1981. Beitrag zur Kenntnis von Morphologie, Taxonomie und geographischer Verbreitung von Mesocyclops leuckarti auctorum. Arch. Hydrobiol./Suppl., 62: 148-190.

Kiefer, F. \& R. Muckle 1959. Beobachtunen am Crustaceenplankton des Überlinger Sees (Bodensee) 1952-1957. I. Das Auftreten der Arten im Jahresverlauf. Beitr. naturk. Forsch. SW-Deutschl., 18: 4-41.

Koski, M., M. Viitasalo \& H. Kuosa. 1999. Seasonal development of meso-zooplankton biomass and production on the SW coast of Finland. Ophelia, 50: 69-91.
Kowalczyk, C. 1958. Die Copepodenfauna der Libiszower Seen. Annales UMCS, Lublin, 12/6, sec. C: 57-101 (in Polish, summary in German).

Kowalczyk, C. 1969. Cladocera and Copepoda of peat-hags in the environs of Parczew. Annales UMCS, Lublin, 24/22, sec. C: 323-339 (in Polish, summary in English).

Lacroix, G. \& F. Lecher-Moutoué. 1984. Diapause des Cyclopoides d'un écosystème lacustre peu profund (w. Lac de Créteil, France). Annls limnol., 20: 183-192.

Lampert, W. \& U. Schober. 1978. Das regelmässige Auftreten von Frühjahrs-Algenmaximum und "Klarwasserstadium" im Bodensee als Folge vom klimatischen Bedingungen und Wechselwirkungen zwischen Phyto- und Zooplankton. Arch. Hydrobiol., 82: 364-386.

Langeland, A. 1982. Interactions between zooplankton and fish in a fertilized lake. Holarct. ecol., 5: 273-310.

Larsen, D.A. 1982. Populasjonsdynamikk til zooplankton $i$ Fievann, et mixotroft kystvann i Aust-Agder, med spesiell vekt på konkurranse og predasjon som regulerende faktorer. Thesis, Univ.Oslo, 166 pp. (Mimeogr. in Norwegian).

Lattin, G. de. 1967. Grundriss der Zoogeographie. Gustav Fischer Ver., Stuttgart: 602 pp.

Litynski, A. 1938. Biocönose und Biosoziation. Arch. Hydrobiol. Ryb., 11: 167-209.

Mäemets, A. 1958. Über den qualitativen Bestand der Krebsfauna der Sommer-Zooplanktons der Seen der Estonischen SSR. Hüdrobioloogilised Uurimused, Academy of sciences of the Estonian S.S.R., Tartu 1: 104-134 (in Russian, summary in German).

Mäemets, A. 1971. Estonian limnology. Academy of sciences of the Estonian S.S.R. Valgus, Tallinn: 95 pp.

Mäemets, A. 1974. On Estonian lake types and main trends of their evolution. In: Estonian wetlands and their life. Estonian contribution to the International Biological Programme, No. 7. Valgus, Tallinn: 29-62,

Mäemets, A. \& E.-J. Haberman. 1971. Preliminiary characterization of zooplankton in Lake Võrtsjärv. Estonian contributions to the International Biological Program, III. Tartu, 1971: 123-164.

Maier, G. 1989. The effect of temperature on the development times of eggs, naupliar and copepodid stages of five species of cyclopoid copepods. Hydrobiologia, 184: 79-88.

Maier, G. 1990. Coexistence of the predatory cyclopoids Acanthocyclops robustus (Sars) and Mesocyclops leuckarti (Claus) in a small eutrophic lake. Hydrobiologia, 198: 185-203.

Maier, G. 1993. An example of niche partitioning in three coexisting freshwater cyclopoid copepods. J. Plankton Res., 15: 1097-1102.

Maier, G. 1994. Patterns of life history among cyclopoid copepods of central Europe. Freshwat. Biol., 31: 77-86.

Maier, G. 1996. Copepod communities in lakes of varying trophic degree. Arch. Hydrobiol., 136: 455-465.

Maier, G. \& R. Buchholz. 1996. Zooplankton communities of gravel pits in relation to trophy, dredging activity and macrophyte growth. Limnologica (Berl.), 26: 353-360.

Mittelholzer, E. 1970. Populationsdynamik und Produktion des Zooplanktons im Greifensee und im Vierwaldstättersee. Schweiz. Z. Hydrol., 32: 90-149.

Markevich, G.I., N.M. Mineeva, L.P. Bykova, L.G. Korneva, E.A. Koreneva \& O.D. Zavoronkova. 1982. Vertical distribution of plankton in Lake Siversko and their seasonal dynamics. In: Ecological investigations in Volgo-Baltic and Sivero-Dinski water systems. Trydy Freshwat. biol. inst., Acad. Sci. USSR, 43 (46): 127-149 (in Russian).

Monakov, A.V. 1959. On the hibernation of Mesocyclops leuckarti Claus in Rybinsk Reservoir. Byull. Inst. Biol. Vodokhr., 5: 18-20 (in Russian, Trans. by J.E.M. Horne, Fresh.Brit.Assoc.). 
Monakov, A.V. 1972. Review of studies on feeding of aquatic invertebrates conducted at the Institute of Biology of inland waters, Academy of sciences, USSR. J. Fish. Res. Board Canada, 29: 363-383.

Monakov, A.V. 1976. Nutrition and trophic relations of freshwater Copepoda. Nauka, Leningrad: 170 pp. (in Russian).

Monakov, A.V. \& Y.I. Sorokin 1959. Experimental studies of the carnivorous feeding of Cyclopoida by means of an isotop method. Rep. Acad. Sci. USSR, 125: 201-204 (in Russian).

Moog, O. 1979. Das Crustaceenplankton des Attersees - Bemerkungen zur Populationsökologie und Stellung in der limnischen Nahrungskette. Arb. Lab. Weyregg, 3/1979: 178-187.

Moore, G.M. 1939. A limnological investigation of the microscopic benthic fauna of Douglas Lake, Michigan. Ecol. Monogr., 9: 537-582.

Naess, T. 1985. En undersøkelse av zooplanktonsamfunnene Vormelitjenn og Søndeledpollen, en limnisk og marin lokalitet ved Søndeled i Aust-Agder. Thesis, Univ.Oslo: 226 pp. (Mimeogr. in Norwegian).

Naess, T. J.P. Nilssen \& R. Demmo. 1993. Individual lake characteristics modify the life cycles and diapause habitat of two neighbouring populations of the cyclopoid copepod Thermocyclops oithonoides. Can. J. Zool., 71: 1663-1672.

Nauwerck, A. 1963. Die Beziehungen zwischen Zooplankton und Phytoplankton im See Erken. Symb. Bot. Upsal., 17/5: $1-163$.

Nilssen, J.P. 1974. Inventeringsundersøkelser i Aust-Agder sommer/høst 1973. Landsplanen for verneverdige områder/forekomster. Ferskvann. Kontaktutvalget for vassdragsreguleringer, Mimeography, in Norvegian.

Nilssen, J.P. 1976. Community analysis and altitudinal distribution of limnetic Entomostraca from different areas in southern Norway. Pol. Arch. Hydrobiol., 23: 105-122.

Nilssen, J.P. 1977. Cryptic predation and the demographic strategy of two limnetic cyclopoid copepods. Mem. Ist. ital. Idrobiol., 34: 187-195.

Nilssen, J.P. 1978. On the evolution of life histories of limnetic cyclopoid copepods. Mem. Ist. ital. Idrobiol., 36: 193-214.

Nilssen, J.P. 1979. Problems of subspecies recognition in freshwater cyclopoid copepods. Z. zool. Syst. Evolut.forsch., 17: 285-295.

Nilssen, J.P. 1980a. When and how to reproduce: A dilemma for limnetic cyclopoid copepods. In: Kerfoot, W.C. (Ed.), Evolution and ecology of zooplankton communities, Univ. Press New England, Hanover: 418-426.

Nilssen, J.P. 1980b. Acidification of a small watershed in southern Norway and some characteristics of acidic aquatic environments. Int. Revue ges. Hydrobiol., 65: 177207.

Nilssen, J.P. \& J.A. Eie. 1974. Inventering av ferskvannsforekomster i Gjerstad, Vegårshei, Risør og Kragerø 1974. Landsplanen for verneverdige områder/forekomster. Ferskvann. Kontaktutvalget for vassdragsreguleringer. Mimeography: 54 pp (in Norvegian).

Nilssen, J.P. \& K. Elgmork. 1977. Cyclops abyssorum - life cycle dynamics and habitat selection. Mem. Ist. ital. Idrobiol., 34: 197-238.

Nyberg, J. 1981. Zooplanktonsamfunnet i Borrevannet, Vestfold, med spesiell vekt på livshistoriene til Cyclops strenuus, Mesocyclops leuckarti og Eurytemora velox. Thesis, Univ.Oslo: 118 pp. (Mimeogr. in Norwegian).

Oksum-Eriksen, T. 1982. Eksperimentelle innhengningsforsøk $i$ Gjersjøen: beiteeffekt og interaksjoner $i$ zooplanktonsamfunnet analysert $i$ småinnhegninger. Thesis, Univ. Oslo: 105pp. (Mimeograph. in Norwegian).
Papinska, K. 1984. The life cycle and the zones of occurrence of Mesocyclops leuckarti Claus (Cyclopoida, Copepoda). Ekol. pol., 32: 493-531.

Papinska, K. 1985. Carnivorous and detrivorous feeding of Mesocyclops leuckarti Claus (Cyclopoida, Copepoda). Hydrobiologia, 120: 249-257.

Papinska, K. \& K. Prejs. 1979. Crustaceans of the near-bottom water and bottom sediments in 24 Masurian lakes with special consideration to cyclopoid copepods. Ekol. pol. 27: 603-624.

Parker, R.A. 1960. Competition between Simocephalus vetulus and Cyclops viridis. Limnol. Oceanogr., 5: 180-189.

Parker, R.A. 1961. Competition between Eucyclops agilis and Daphnia pulex. Limnol. Oceanogr., 6: 299-301.

Patalas, K. 1954a. Quantitative investigations on the diurnal and seasonal variations in the distribution of the pelagic Crustacea in the Charzykowo lake. Pol. Arch. Hydrobiol., 2: 31-155 (in Polish, summary in English).

Patalas, K. 1954b. Plankton Crustacea as a food base for the small whitefish (Coregonus albula) population in the Charzykowo lake. Pol. Arch. Hydrobiol., 2: 259-276 (in Polish, summary in English).

Patalas, K. 1956. Seasonal changes in a community of pelagic Crustacae in the Zamkowe Lake on the background of thermo-oxygen conditions. Pol. Arch. Hydrobiol., 3: 259276 (in Polish, summary in English).

Patalas, K. 1963. Vertical distribution of crustacean plankton in morphologically differentiated lakes of Wegorzewo district. Rocz-i Nauk Roln. Ser., 82-B-2: 195-207 (in Polish, summary in English).

Patalas, K. 1986. The geographical distribution of Mesocyclops edax (S.A. Forbes) in lakes of Canada. Syllogeus, 58: 400-408.

Patalas, J. \& K. Patalas. 1961. The crustacean zooplankton in morphologically different lakes of Wdzydze complex. Rocz-i Nauk Roln. Ser., 93-D: 111-139 (in Polish, summary in English).

Patalas, J. \& K. Patalas. 1966. The crustacean plankton communities in Polish lakes. Verh. int.Ver. Limnol., 16: 204215 .

Patalas, J. \& K. Patalas. 1968. Crustacean zooplankton of some Mazurian lakes characterized by different fish yield. Pol. Arch. Hydrobiol., 15: 289-304.

Podbolotova, T.I. \& O.I. Potapova. 1972. The food of largesized vendace (Coregonus albula L.) in the South-Karelian lakes. In: Potapova, O.I. \& Y.A. Smirnov (Eds.), Salmonidae of Karelia, Issue 1, Ecology, parasites, biochemistry. Karelian branch of the USSR academy of sciences, institute of biology, Petrozavodsk: 110-121 (in Russian).

Prejs, K. \& K. Papinska. 1983. Ecological characteristics of lakes in north-eastern Poland versus their trophic gradient. XI. Meiobenthos and near-bottom meiofauna in 20 lakes. Ekol. pol., 31: 477-493.

Proszynska, M. 1963. On the problem of differentiating Cladocera and Copepoda fauna in ponds and small water bodies in the light of present faunistic literature. Pol. Arch. Hydrobiol., 11: 77-96.

Ravera, O. 1954. La struttura demografica dei Copepodi del Lago Maggiore. Mem. Ist. ital. Idrobiol., 8: 109-150.

Ravera, O. 1955. Seasonal variation of the reproductive rate in pelagic copepods of Lago Maggiore. Verh. int. Ver. Limnol., 12: 436-446.

River, I.K., I.M. Lebedeva \& N.K. Ovsjinikova. 1982. Longterm dynamics of zooplankton in Rybinsk Reservoir. In: Ecology of water organisms in Upper Volga reservoirs. Trydy Freshwat. biol. inst., Acad. Sci. USSR, 45 (48): 6987 (in Russian).

Rodhe, W. 1941. Zur Verbesserung der quantitativen Planktonmetodik nebst Profilen des Crustaceenplanktons aus drei småländischen Seen. Zool. bidr. Upsal., 20: 465-477. 
Røen, U. 1957. Contributions to the biology of some Danish free living freshwater copepods. Biol. Skr. Dan. Vid. Selsk., 9/2: 1-101.

Rylov, W.M. 1963. Freshwater Cyclopoida. Fauna of the USSR. Crustacea. III (3). Israel progr. for scient.trans: 318 pp.

Sandøy, S. 1984. Zooplanktonsamfunnet $i$ to forsura vatn $i$ Gjerstad i Aust-Agder. Virkning av biotiske og abiotiske faktorar på livssyklus og populasjonstetthet. Thesis, Univ.Oslo, 247pp. (Mimeogr. in Norwegian).

Sandøy, S. \& J.P. Nilssen. 1987. Cyclopoid copepods in marginal habitats: Abiotic control of population densities in anthropogenic acidic lakes. Arch. Hydobiol./Suppl., 76: 236-255.

Sanni, S. \& S.B. Wærvågen. 1990. Oligotrophication as a result of planktivorous fish removal with rotenon in the small, eutrophic Lake Mosevann, Norway. Hydrobiologia, 200/201: 263-274.

Santer, B. 1993. Do cyclopoid copepods control Daphnia populations in early spring, thereby protecting their juvenile instar stages from food limitation? Verh. int. Ver. Limnol., 25: 634-637.

Santer, B. 1996. Nutritional suitability of the dinoflagellate Ceratium furcoides for four copepods species. J. Plankton Res., 18: 323-333.

Santer, B. \& W. Lampert. 1995. Summer diapause in cyclopoid copepods: adaptive response to a food bottleneck? $J$. Anim. Ecol., 64: 600-613.

Santer, B. \& E. Boldt. 1998. The seasonal patterns of lipids in the life cycle of the summer-diapausing freshwater copepod Cyclops kolensis (Lilljeborg). Arch. Hydrobiol. Spec. Issue Advanc. Limnol., 52, 477-492.

Sargent, J.R. 1978. Marine wax esters. Sci. Prog. Oxf. (1978), 65: 437-458.

Sars, G.O. 1863. Oversigt af de indenlandske Ferskvands-Copepoder. Forhandl. Vidensk.-Selskab. Christiania, (1862): 212-262 (in Norwegian).

Sars, G.O. 1918. An account of the Crustacea of Norway. Vol. 4: Copepoda Cyclopoida. Bergen Museum, 1918. 225 pp., 108 figures.

Sarvala, J. 1979. Benthic resting periods of pelagic cyclopoids in an oligotrophic lake. Holarc. Ecol., 2: 88-100.

Schindler, D.W. 1969. Two useful devices for vertical plankton and water sampling. J. Fish. Res. Bd Can., 26: 19481953.

Schönberg, N. 1961. Über die Biologie einiger pelagischer Kopepodenarten im See Võrtsjärv. Hüdrobioloogilised Uurimused, Academy of sciences of the Estonian S.S.R., Tartu 2: 159-193 (in Russian, summary in German).

Sirkova, Z.N. \& F.D. Mordukaj-Boltovskoj. 1979. On the microbenthos of lake Belog, system of the Severo-Dinski Canal. Trydy Acad. Sci. Vnutr. Vod, 22 (25): 63-81 (in Russian).

Skadovsky, S.N. 1926. Über die aktuelle Reaktion der Süsswasserbecken und ihre biologische Bedeutung. Verh int.Ver. Limnol., 3: 109-144.

Skogheim, O.K. 1979. Beskrivelse av en sedimenthenter konstruert for prøvetakning av korte sedimentkjerner. Rapport fra Årungenprosjektet 1979/2: 1-7 (in Norwegian, Abstract in English).

Sladecek, V. 1950. Studies of the zooplankton of the ponds of Padrt (Bohemia) with special reference to the cladoceran Holopedium gibberum. Bull. int. Acad. thèche 1950, 51/22: 1-28.

Smyly, W.J.P. 1957. Distribution and seasonal abundance of Entomostraca in moorland ponds near Windermere. $\mathrm{Hy}$ drobiologia, 11: 59-72.

Smyly, W.J.P. 1961. The life cycle of the freshwater copepod Cyclops leuckarti in Esthwaite Water. J. Anim. Ecol., 30: 153-171.
Smyly, W.J.P. 1962. Laboratory experiments with stage V copepodids of the freshwater copepod, Cyclops leuckarti Claus, from Windermere and Esthwaite Water. Crustaceana, 4: 273-280.

Smyly, W.J.P. 1964. An investigation of some benthic Entomostraca of three lakes in Northern Italy. Mem. Ist. ital. Idrobiol., 17: 33-56.

Smyly, W.J.P. 1968. Observations on the planktonic and profundal Crustacea of the lakes of the British Lake District. J. Anim. Ecol., 37: 693-708.

Smyly, W.J.P. 1974. The effects of temperature on the development time of the eggs of three freshwater cyclopoid copepods from the English Lake District. Crustaceana, 27: 278-284.

Smyly, W.J.P. 1980. Food and feeding of the aquatic larvae of the midge Chaoborus flavicans (Meigen)(Diptera: Chaoboridae) in the laboratory. Hydrobiologia, 70: 179-188.

Spanovskaya, V.D. \& V.A. Grygorash. 1977. Development and food of age-0 Eurasian perch (Perca fluviatilis) in reservoirs near Moscow, USSR. J. Fish. Res. Board Can., 34: $1551-1558$

Spikkeland, I. 1998. Dyreliv i dammer i Askim. Natur i Østfold, 17: 13-22 (in Norwegian).

Sramek-Husek, R. 1948. Types of water and zooplankton occuring in the area of the lake Velke Darko. Vest. Csl. zool. spol., 12: 210-230 (in Czech, summary in English).

Stebler, R. 1979. Das pelagische Crustaceenplankton des Bielersees: Abundanzdynamik, Produktion and Sukzession. Schweiz. Z. Hydrol., 41: 1-37.

Stolbunova, V.N. 1985. Long-term dynamics of zooplankton in Ivanosko Reservoir. In: Water communities and biology of water organisms. Trydy Freshwat. biol. inst., Acad. Sci. USSR, (52) 55: 50-59 (in Russian).

Straskraba, M. 1963. Share of the littoral region in the productivity of two fishponds in southern Bohemia. Rozpravy $C Z A V$, rada $M P V, 73,13: 1-64$.

Sushchenya, L.M. 1975. Quantitative aspects of feeding of Crustacea. Izdat. Nauka Technika, Minsk: 226 pp (in Russian).

Szlauer, L. 1958. The plankton of the Chelmzynskie Lake. Zesz. Nauk. UMK, 2, biol: 33-61 (in Polish, summary in English).

Szlauer, L. 1963. The resting stages of Cyclopoidae in Stary Dwor Lake. Pol. Arch. Hydrobiol., 11: 385-394.

Szlauer, L. 1969. Response of lake fauna to light. Pol. Arch. Hydrobiol., 13: 233-244.

Szlauer; L. \& J. Widuto. 1966. The Crustacea plankton in the Sukiel Lake in the years 1955-1957. Zesz. Nauk.WSR Olsztyn, 21: 733-755 (in Polish, summary in English).

Taube, I. \& A. Neuwerck. 1967. Zur Populationsdynamik von Cyclops scutifer Sars. I. Die Temperaturabhängigkeit der Embryonalentwicklung von Cyclops scutifer Sars im Vergleich zu Mesocyclops leuckarti (Claus). Rep. Inst. Freshwat. Res. Drottningholm, 47: 76-86.

Threlkeld, S.T. \& J.M. Dirnberger. 1986. Benthic distribution of planktonic copepods, especially Mesocyclops edax. Syllogeus, 58: 481-486.

Twombly, S. 1993. Inter- and intrapopulational variation in time to metamorphosis in a freshwater copepod. Freshwat. Biol., 30: 105-118.

Twombly, S. 1995. Phenotypic variation in metamorphosis in four species of freshwater copepods. Freshwat. Biol., 34: 29-38.

Ulomski, S.N. 1953. New ecological studies of some species of oar-legged crustaceans (Copepoda), Mesocyclops leuckarti Claus. Dokl. Akad. Nauk USSR, 90: 295-297 (in Russian).

Van der Velde, I. 1984. Revision of the African species of the genus Mesocyclops Sars, 1914 (Copepoda, Cyclopoida). Hydrobiologia, 109: 3-66. 
Vijverberg, J. 1977. Population structure, life histories and abundance of copepods in Tjeukemeer, the Netherlands. Freshwat. Biol., 7: 579-597.

Vijverberg, J. 1980. Effect of temperature in laboratory studies on development and growth of Cladocera and Copepoda from Tjeukemeer, The Netherlands. Freshwat. Biol., 10: 317-340.

Vijverberg, J. \& A.F. Richter. 1982. Population dynamics and production of Acanthocyclops robustus (Sars) and Mesocyclops leuckarti (Claus) in Tjeukemeer. Hydrobiologia, 95: 261-274.

Vranovsky, M. 1964. Zur Kenntnis der Herbst- und Frühjahrsfauna der Cyclopoida (Crustacea, Copepoda) der Moore im oberen Orava-gebiet (Nordwestslowakei). Biologia (Bratislava), 19: 424-439.

Vuille, T. 1991. Abundance, standing crop and production of microcustacean populations (Cladocera, Copepoda) in the littoral zone of Lake Biel, Switzerland. Arch. Hydrobiol., 123: $165-185$

Vuorinen, I., M. Rajasilta \& J. Salo. 1983. Selective predation and habitat shift in a copepod species - support for the predation hypothesis. Oecologia (Berl.), 59: 62-64.

Wærvågen, S.B. 1985. En limnologisk studie av Gjerstadvann i Aust-Agder, med spesiell vekt på zooplanktonsamfunnets livshistorier og populasjonsdynamikk. Thesis, Univ.Oslo: 177 pp. (Mimeogr. in Norwegian).

Wappis, E. 1980. Zur Populationsökologie des Zooplanktons des Ossiacher Sees. Thesis, Univ.Graz: 168 pp.

Wesenberg-Lund, C. 1904. De danske søers og dammers dyriske plankton. E. Munksgaard, Copenhagen.

Wierzbicka, M. 1962. On the resting stage and mode of life of some species of Cyclopoida. Pol. Arch. Hydrobiol., 10: 215-229.

Received: April 2000

Accepted: May 2000
Wierzbicka, M. 1972. The metabolic products of copepodids of various Cyclopoida species during their resting stage. Pol. Arch. Hydrobiol., 19: 279-290.

Wierzbicka, M. 1974. Haemolymph concentration in Cyclopoida copepodids during active and resting stage and the effect of 2,4-D sodium salt. Pol. Arch. Hydrobiol., 21: 269-273.

Wierzbicka, M. \& S. Kedzierski. 1964. On the dormancy state of some species of Cyclopoida under experimental and natural conditions. Pol. Arch. Hydrobiol., 12: 47-80.

Wierzbicka, M. \& S. Kedzierski. 1970. Contents of lipids in resting stages of Copepoda, Cyclopoida. Pol. Arch. Hydrobiol., 17: 289-293.

Williamson, C.E., 1980. The predatory behaviour of Mesocyclops edax: Predator preferences, prey defences, and starvation-induced changes. Limnol. Oceanogr., 25: 903-909.

Williamson, C.E. \& R.E. Magnien. 1982. Diel vertical migration in Mesocyclops edax: implications for predation rate estimates. J. Plankt. Res., 4: 329-339.

Winfield, I.J. \& C.R. Townsend. 1983. The cost of copepod reproduction: increased susceptibility to fish predation. Oecologia (Berl.), 59: 406-411.

Yufeng, Y. 1998. Feeding of Mesocyclops leuckarti on Moina and Diaphanosoma. Zool. Res., 19: 31-37.

Yufeng, Y., H. Xiangfei \& L. Jiankang. 1999. Long-term changes in crustacean zooplankton and water quality in a shallow, eutrophic Chinese lake densely stocked with fish. Hydrobiologia, 391: 195-203.

Zawislak, W. \& L. Bittel. 1971. Seasonal variability of the zooplankton in the southern part of the Lake Jeziorak, with a special consideration of its littoral. Zesz. Nauk. UMK, 27, prac. limnol., 6: 81-114.

Zhdanova, G.A. \& T.V. Frinovskaya. 1979. Variations in fecundity of planktonic Crustacea in the Kiev reservoir and in the laboratory. Gidrobiol. Zh., 15: 10-16. 